\title{
Cocaine, Race, and Equal Protection
}

\section{David A. Sklansky*}

Most agree that equal protection should guard against laws that disproportionately burden members of a disempowered minority group because of majority prejudice. In this essay, Professor Sklansky argues that equal protection doctrine in its current form fails to achieve this objective. Professor Sklansky reaches this conclusion through an examination of the manner in which courts have upheld the constitutionality of the mandatory federal sentences for trafficking in crack cocaine. Those sentences are far harsher than the penalties federal law prescribes for trafficking in powder cocaine, the precursor of crack cocaine. Professor Sklansky argues that current equal protection doctrine leads courts to ignore troubling evidence that the crack cocaine sentences are so severe at least in part because, unlike the powder cocaine penalties, they are imposed almost exclusively on black defendants. He suggests that an excessive insistence on doctrinal consistency and simplicity has blinded equal protection law to important issues of racial injustice, including the danger that the crack cocaine penalties are the product of unconscious racism. In order to foster a gradual, case-by-case improvement of equal protection law, Professor Sklansky calls for greater toleration of doctrinal disorder.

A country is the things it wants to see. ${ }^{1}$

Thousands of federal prisoners, including a few I helped prosecute, are currently serving long mandatory sentences for trafficking in crack cocaine. Nine out of ten of them are black. They were sentenced under laws that treat crack offenders far more harshly than the predominantly nonblack defendants caught with the more common, powder form of cocaine. Indeed, since 1986 federal crack defendants have received by law the same sentences imposed on defendants convicted of trafficking in one hundred times as much cocaine powder. Almost without exception, constitutional claims of unequal treatment raised by the crack defendants have been rejected out of hand. This essay examines why that is so, and what it tells us about the state of equal protection law. What it

* Acting Professor of Law, UCLA School of Law. From 1987 to 1994 I was a federal prosecutor in the Office of the United States Attorney for the Central District of California. This essay does not express the views of that office or of the United States Department of Justice.

This essay could not have been written without the encouragement and support of the faculty, students and staff of the UCLA School of Law. I owe special thanks to Peter Arenella, Evan Caminker, Raquelle de la Rocha, Julian Eule, Robert Goldstein, Laura Gómez, Pamela Karlan, Kenneth Karst, Deborah Lambe, Gillian Lester, Jeff Sklansky, Mark Sklansky, Eugene Volokh, and John Wiley for helpful criticism and suggestions; to the UCLA School of Law Dean's Fund for financial support; to Kavita Jain, Nina Sethi, and the staff of the Hugh and Hazel Darling Law Library for research assistance; and to the members of the Stanford Low Review for careful and constructive editing.

1. Robert Pinsky, An Explanation of America 8 (1979). 
tells us, I argue, is that there are certain important dimensions of racial injustice our law does not see.

There are many ways to evaluate a set of legal rules, in part because there are many things we want the law to do. The assumption underlying my approach is that one thing we should want legal rules to do is to take into account the important aspects of the situations they address. ${ }^{2}$ A set of rules that satisfies this requirement may yet be unfair, unworkable, or otherwise undesirable, but at least it will not be blind to its own major shortcomings. Nor will it tend to blind those who apply it.

These modest boasts, I suggest, cannot be made for equal protection doctrine in its current form. In Part I of this essay, I describe a test case: the heavy mandatory sentences imposed by federal law on defendants, almost all of them black, convicted of trafficking in crack cocaine. After reviewing the background and operation of the laws governing federal narcotics sentences, I argue that the crack sentences raise troubling issues of fairness that we should want equal protection doctrine to address. These issues arise, I contend, even under the relatively narrow, process-oriented conception of equality that has dominated equal protection discussions in recent years.

Part II examines what has happened when black defendants convicted of crack trafficking have raised equal protection challenges to their sentences. Federal appellate courts have uniformly rejected these challenges, based on a largely mechanical application of the equal protection rules developed by the Supreme Court. I suggest that those rules systematically ignore, and lead judges and others to ignore, much of what is most troubling about the crack sentences: the evidence of at least unconscious racism on the part of Congress, the severity of the disparity between the average sentences imposed on black defendants and those imposed on whites, and the special need to avoid racial bias when meting out criminal punishment.

In Part III, I offer some tentative thoughts about how equal protection doctrine became so feeble-sighted, and how it could be made more perceptive. Much of the problem, I suggest, may arise from a doctrinal discussion carried out at too high a level of generality. For at least the past two decades the Supreme Court, along with many of its critics, has tended to assume that equal protection doctrine should remain relatively uniform regardless of factual context: the test for unconstitutional inequality in criminal sentencing, for example, should be the same as in civil service promotions. This universalist approach has strong theoretical advantages for constructing equal protection rules for an ideal society. In our real and imperfect society, however, the universalist approach has proved disastrous. It has blocked consideration of equal protection claims that should be taken seriously, and it has stifled the development of our collective understanding of equality.

2. My approach is similar in some ways to that of Todd Rakoff, who has stressed that doctrine "highlights certain social processes and hides others," and has criticized current equal protection doctrine for failing to "account for our normal understanding of political life." See Todd Rakoff, Washington v. Davis and the Objective Theory of Contracts, 29 HARv. C.R.-C.L. L. REv. 63, 63, 73 (1994). Rakoff's conclusions, however, differ from mine. See note 148 infra. 
There are obvious risks in drawing broad conclusions from a single example-particularly conclusions about a subject that has received as much thoughtful, wide-ranging scholarly attention as equal protection. Animating this essay is the hope that, for scholars as well as judges, small-scale efforts at "thick description"3 can usefully complement larger-scale studies. In using a particular example to suggest that our current approach to equal protection pays too little attention to particulars, this essay aims, in other words, both to plead for and to demonstrate "the generative, educative potential of specific facts."4

Inequality tends, notoriously, to be accompanied and sustained by ways of thinking that render it imperceptible to those it benefits, and sometimes also to those it burdens. Many of these ways of thinking have been and remain jurisprudential. But law need not obscure more than it reveals. Indeed, one of the most important functions served on occasion by equal protection law has also been the simplest: identifying inequality and helping to deny it the protection of invisibility. How our law could serve that purpose more often is the question at the heart of this essay.

\section{A Test Case Described}

\section{A. Federal Crack Sentences and Black Defendants}

Almost half of all federal criminal defendants are prosecuted for narcotics offenses. ${ }^{5}$ The sentences they receive reflect the confluence a decade ago of two broad trends in public policy: a reduction of judicial discretion in sentencing, and an increased concern about drug abuse.

The first trend began in the 1970 s and continues, more or less, to this day. ${ }^{6}$ Its clearest expression is the Sentencing Reform Act of $1984,{ }^{7}$ which established the United States Sentencing Commission and charged it with developing and promulgating a comprehensive system of "Sentencing Guidelines."

3. Clifford GeERTz, Thick Description: Toward an Interpretive Theory of Culture, in ThE INTERPRETATION OF CULTURES 3 (1973).

4. Katharine T. Bartlett, Feminist Legal Methods, 103 Harv. L. Rev. 829, 852 (1990); cf. LuDwig Wittgenstein, PhIIosophical Investigations § 79, at 37e (G.E.M. Anscombe trans., 3d ed. 1958) ("Say what you choose, so long as it does not prevent you from seeing the facts. (And when you see them there is a good deal that you will not say.)").

As will be apparent, my analysis draws heavily on a range of scholarship that addresses equal protection more broadly, particularly the writings of Paul Brest, John Hart Ely, Kenneth Karst, and Charles Lawrence. I draw, too, on Justice Marshall's repeated criticism of equal protection doctrine as insufficiently sensitive to factual context, although the remedy of doctrinal disaggregation I ultimately propose differs from the unified approach he championed. See note 137 infra; text accompanying notes 150-166 infra.

5. See U.S. Sentencing Commission, Annual Report 57 (1993) [hereinafter 1993 Annual RepORT]; U.S. SENTENCING COMMIISSION, ANNUAL REPORT 46 (1992) [hereinafter 1992 ANNUAL Report]; Douglas C. McDonald \& Kenneth E. Carlson, Sentencing in the Federal Courts: Does Race Matter?, The Transition to Sentencing Guidelines, 1986-1990, at 40, 83 (1993).

6. See, e.g., Violent Crime Control and Law Enforcement Act of 1994, Pub. L. No. 103-322, $\S 70001,108$ Stat. 1796 (1994) (to be codified at 42 U.S.C. $\S 13,701$ ) (adding mandatory sentence of life imprisonment for repeat offenders convicted of certain violent felonies); LAWRENCE $M$. FrIEDMAN, Crime and Punshment in American History 411 -13 (1993); David J. Rothman, The Crime of Punishment, N.Y. Rev. Books, Feb. 17, 1994, at 35-36.

7. Pub. L. No. $98-473, \S \S 211-38,98$ Stat. 1987-2040 (1984) (codified as amended in scattered sections of 18 U.S.C. and at 28 U.S.C. $\S \S 991-98$ ). 
The Sentencing Commission disseminated its initial set of Guidelines in 1987 and has since repeatedly amended them. ${ }^{8}$ Despite their name, the Guidelines are binding, not hortatory, and they drastically restrict the discretion of the sentencing judge. ${ }^{9}$

For most federal defendants convicted of narcotics trafficking, however, the Sentencing Reform Act pales in importance beside the Anti-Drug Abuse Act of $1986,{ }^{10}$ the major legislative response to the dramatic changes during the $1980 \mathrm{~s}$ in public attitudes toward drug abuse. Public concern about narcotics has ebbed and flowed over the past one hundred years, ${ }^{11}$ and the 1980 s witnessed yet another turning of the tide. During that decade, drug abuse was transformed in the public mind from a social problem of moderate importance to a national crisis of the first order. ${ }^{12}$ Congress and the President responded in 1986 with a flurry of activity culminating in the Anti-Drug Abuse Act, signed into law one week before the November midterm elections. Among the Act's provisions were stiff mandatory minimum sentences for narcotics traffickingthe stiffest, in many respects, in the history of American narcotics laws. ${ }^{13}$

8. See U.S. Sentencing Commission, Federal Senmtenctng Guidelines Manual (1993) [hereinafter GudDelines MANUAL]. The Supreme Court upheld the constitutionality of the Guidelines against delegation and separation-of-powers arguments in Mistretta v. United States, 488 U.S. 361 (1989).

9. See, e.g., Terence Duckworth \& Charles D. Weisselberg, Felony Cases and the Federal Courts: The Guidelines Experience, 66 S. Cax. L. Rev. 99 (1992); Daniel J. Freed, Federal Sentencing in the Wake of Guidelines: Unacceptable Limits on the Discretion of Sentencers, 101 YALE L.J. 1681 (1992).

10. Pub. L. No. 99-570, 100 Stat. 3207 (1985) (codified as amended in scattered sections of 18 U.S.C., 21 U.S.C., 31 U.S.C., 42 U.S.C.). 40.

11. David F. Musto, Opium, Cocaine and Marijuana in American History, Scr. AM., July 1991, at

12. See Bureau of Justice Statistics, U.S. Department of Justice, Drugs, Crime, and the Justice SYSTEM 95 (1992) (noting that "[o]ver the past six years, drug abuse has consistently been mentioned as one of the most important problems facing the country"); America's Crusade, Time, Sept. 15, 1986, at 60,61 (describing drugs as "this year's public bane'); Peter Kerr, Anatomy of the Drug Issue: How, After Years, It Erupted, N.Y. Times, Nov. 17, 1986, at A1. The percentage of Americans naming drugs as the factor most responsible for crime rose from $13 \%$ in 1981 to $58 \%$ in 1989 . BuREAU OF Justice Statistics, supra, at 93; see also 132 Cong. Rec. 26,464 (1986) (remarks of Sen. Moynihan) (noting that the percentage of Americans naming drugs as the nation's most important problem rose from $2 \%$ in April 1986 to $13 \%$ in September 1986).

13. Before 1986 the undisputed "high point of federal punitive action against narcotics" was the Boggs Act of 1951, Pub. L. No. 82-255, 65 Stat. 767 (1951), as amended and strengthened by the Narcotic Control Act of 1956, Pub. L. No. 84-728, 70 Stat. 567 (1956). David F. Musto, M.D., ThE american Disease: Origins of Narcotic Control 231 (1987). For most first offenders, these statutes imposed minimum sentences of two years for possession of a narcotic and five years for trafficking. Sentences were significantly higher for repeat offenders. See The President's Advisory Commission on Narcotic and DRUG ABuse, Final RePORT 39-40 (1963) (describing then-existing mandatory minimum penalties).

The narcotics penalties enacted in 1951 and 1956 represented, at least at the federal level, the nation's first comprehensive set of mandatory minimum sentences. See U.S. SENTENCING COMMISSION, Mandatory Mnimum Penalties in the Federal Criminal Justice System 5 (1991). Most of these penalties were repealed in 1970. See Comprehensive Drug Abuse Prevention and Control Act of 1970, Pub. L. No. 91-513, 84 Stat. 1236 (1970). The Anti-Drug Abuse Act of 1986, however, revived the close association between mandatory minimum sentences and narcotics crimes: from 1984 to 1990, over $91 \%$ of all cases sentenced pursuant to statutorily mandated minimum penalties involved drug offenses. See U.S. Sentencing Commission, supra, at 10-12. 
The mandatory minimum sentences enacted in 1986 have remained largely unchanged. ${ }^{14}$ For the most part, they apply to defendants who possess or sell quantities of narcotics supposedly indicative of relatively large-scale dealing. For quantities that Congress believed would generally be in the hands of a "kingpin" or "major trafficker"-1000 grams of heroin, for example, or 5000 grams of powder cocaine-the law prescribes a mandatory minimum prison sentence of ten years. ${ }^{15}$ Defendants caught with quantities at one-tenth the "kingpin" level-i.e., 100 grams of heroin or 500 grams of powder cocainereceive a mandatory minimum sentence of five years, ${ }^{16}$ because Congress believed that these lower quantities would generally be possessed by "middlelevel dealers."17

Crack cocaine, however, is treated differently. As with other drugs, the statute sets quantity thresholds of crack cocaine that trigger mandatory minimum sentences of ten and five years. But Congress did not set the thresholds at quantities it believed indicative of a "kingpin," a "major trafficker," or a "middle-level dealer." Instead, Congress fixed the thresholds for crack simply by dividing the thresholds for powder cocaine by 100: fifty grams, instead of 5000 grams, for a ten-year mandatory minimum sentence; and five grams, rather than 500 grams, for a five-year mandatory minimum sentence. ${ }^{18}$ Trafficking in five grams or even fifty grams of powder cocaine carries no mandatory minimum sentence under the statute.

The 100:1 ratio between the sentencing thresholds for powder cocaine and crack is mirrored in the Sentencing Guidelines promulgated in 1987. For de-

14. The 1994 crime legislation exempts from the statutory minimum sentences any defendant with a minimal criminal record who commits an unaggravated drug offense and then cooperates fully with law enforcement authorities. See Violent Crime Control and Law Enforcement Act of 1994, Pub. L. No. 103-322, tit. VIII, $\S 80001$ (a), 108 Stat. 1796, 1985 (1994) (to be codified at 18 U.S.C. $\S 3553(\mathrm{f})$ ). For any such defendant for whom the statutory minimum sentence would otherwise be five years, Congress directed the Sentencing Commission to ensure that the sentencing guidelines require a sentence of at least 24 months. See id. at $\S 80001(b)(1)(B)$.

15. 21 U.S.C. $\S 841$ (b)(I)(A) (1988 \& Supp. V 1993); 132 CoNG. REC. 27,193 (1986) (remarks of Sen. Byrd) ("For the kingpins - the masterminds who are really running these operations-and they can be identified by the amount of drugs with which they are involved - we require a jail term upon conviction. If it is their first conviction, the minimum term is ten years.'); id. at 26,473 (section-by-section analysis of S. 2878) ("The most serious drug traffickers, so-called 'drug kingpins[,]' would face a mandatory minimum of ten years, and up to life imprisonment.").

16. 21 U.S.C. $\S 841(\mathrm{~b})(1)(B)$ (1988 \& Supp. V 1993).

17. 132 CoNG. REC. 27,194 (1986) (remarks of Sen. Byrd) ("Our proposal would also provide mandatory minimum penalties for the middle-level dealers as well.... The minimum sentences would be slightly less than those for the kingpins, but they nevertheless would have to go to jail-a minimum of 5 years for the first offense and 10 years for the second.").

The empirical basis for the specific quantity thresholds selected by Congress appears to have been largely anecdotal, derived from calls to law enforcement officers who reflected upon their personal experiences, and information from districts of particular legislators. Hearings on Proposed Guideline Amendments for Public Comment Before the United States Sentencing Commission 3 (Mar. 22, 1993) [hereinafter Hearings] (testimony of Eric E. Sterling). Sterling was counsel to the House Judiciary Committee Subcommittee on Crime in 1986. Id. at 1 .

18. See 21 U.S.C. $\S 841$ (b)(1)(A)(iii), (B)(iii) (1988 \& Supp. V 1993). Subsequent legislation applied the five-year mandatory minimum sentence even to possession of five grams of crack for purely personal use. See Pub. L. No. 101-647, tit. XII, § 1201, 104 Stat. 4789, 4829 (1990) (codified at 21 U.S.C. $\$ 844(a))$ (1988 \& Supp. V 1993). There are no parallel provisions for powder cocaine or other drugs. 
fendants caught with quantities of narcotics above or below the thresholds for five- and ten-year mandatory minimum sentences, the Guidelines prescribe sentences extrapolated from those required by the Anti-Drug Abuse Act. Thus, with no aggravating or mitigating circumstances, a defendant would be sentenced to ten to sixteen months for trafficking in twenty-five grams of powder cocaine or only a fourth of a gram of crack, seventy-eight to ninety-seven months for two kilograms of powder cocaine or twenty grams of crack, and thirty years to life for 1500 kilograms of powder cocaine or fifteen kilograms of crack. ${ }^{19}$ At every quantity level federal defendants convicted of trafficking in crack cocaine receive the same sentences as defendants convicted of trafficking in one hundred times as much powder cocaine. ${ }^{20}$

The treatment of crack cocaine thus departs strikingly from the overall logic of the Anti-Drug Abuse Act. Neither Congress nor the Sentencing Commission has ever suggested that a defendant caught with fifty grams of crack is likely to be a "kingpin" or a "major trafficker," or that someone with five grams of crack is probably a "middle-level dealer." Indeed, crack is made from powder cocaine, and because the conversion is so easy, it tends to take place toward the end of the drug distribution chain. ${ }^{21}$ As Congress appears to have recognized, large-volume drug traffickers generally do not deal in crack; they deal in its precursor, powder cocaine.22 Defendants caught trafficking in crack thus are almost always the street-level retailers of the cocaine trade, not the wholesalers. ${ }^{23}$

19. See Guddelnnes Manual, supra note 8, ch. 5, pt. A. The Guidelines provide for adjustments of the sentencing range if, among other things, the defendant has a prior criminal history, id. $\S 2 D 1.1(a)(1) \&$ Ch. 4, Pt. A, the offense results in death or serious bodily injury, id. $\S 2 \mathrm{D} 1.1(\mathrm{a})(1)$ \& (2), the defendant carries a weapon, id. §2Dl.1(b)(1), the defendant supervises others in carrying out the offense, id. §3B1.1, or the defendant's participation in the offense is "minimal" or "minor," $i d$. §3B1.2.

20. Several states similarly penalize crack offenses more harshly than offenses involving like amounts of powder cocaine. For a useful overview of the pertinent state statutes, see Knoll D. Lowney, Smoked Not Snorted: Is Racism Inherent in Our Crack Cocaine Laws?, 45 WASH. U.J. URB. \& CoNTEMP L. 121 (1994).

21. As Judge Harold Greene has noted, "[t]he conversion of cocaine powder to crack ... is easily accomplished by anyone with access to a stove or microwave oven. Moreover, it only takes a matter of minutes." United States v. Shepherd, 857 F. Supp. 105, 109 (D.D.C. 1994). On the basis of his ovm docket, Judge Greene took judicial notice "that many, if not most, crack dealers cook their own product." Id. at 110; see also, e.g., 132 CoNG. REc. E259 (daily ed. July 22, 1986) (remarks of Rep. Garcia) (noting that crack "is produced almost anywhere and in small quantities").

22. See, e.g., 132 Cong. Rec. 14,822 (1986) (remarks of Sen. D'Amato) (observing that under then-existing law "a crack dealer cannot be subject to the maximum prison term unless he is caught with a kilogram, or more than 15,000 doses, of crack. This simply never happens.") Senator D'Amato noted Newsweek's observation that "[p]olice raids on 'crack houses' typically recover too little cocaine to impress prosecutors or the courts." Id. (quoting Crack and Crime, NEwsweEk, June 16, 1986, at 16).

23. Jim Newton, Harsher Crack Sentences Criticized as Racial Inequity, L.A. TmEs, Nov. 23, 1992 , at A1, A20 ("The largest-scale cocaine traffickers ... usually smuggle powder cocaine, not crack. Crack dealers are more likely to be street-level drug pushers than big-time cartel bosses.'). Because of "the extreme anomalies in sentencing produced by such a differential in penalties between two easily convertible forms of the same drug," the Sentencing Commission recommended in a February 1995 report to Congress that the 100:1 ratio "be re-examined and revised." U.S. SENTENCING COMMISSION, Cocaine and Federal Sentencing Policy 197 (1995). In April the Commission voted, 4 to 3, to amend the Sentencing Guidelines to eliminate any distinction between crack and powder cocaine; unless rejected by Congress that amendment will take effect November 1, 1995. The Department of Justice has 
They are also almost always black. From October 1991 through September 1992, more than 91 percent of all federal crack defendants were black; only 3 percent were white. ${ }^{24}$ During this same period, by way of contrast, blacks accounted for only slightly over 27 percent of federal prosecutions for powder cocaine and 28 percent of federal prosecutions generally; 32 percent of the powder cocaine defendants, and more than 45 percent of all federal defendants, were white. ${ }^{25}$ The particularly harsh federal penalties for trafficking in crack cocaine thus have a particularly disproportionate impact on black defendants.

The reasons for this disproportionate impact are probably several. First, crack use is strongly concentrated in inner city, black communities, in part because crack is cheap, and in part for the same reasons drug abuse in general is concentrated in economically marginalized areas. ${ }^{26}$ Second, crack dealing appears to be even more strongly concentrated in the inner city, in part because that is where the customers are, and in part because inner city youth have fewer attractive alternatives for earning money. ${ }^{27}$ Third, police and prosecutors in some cases may pay a disproportionate amount of attention to crack dealing in inner city neighborhoods, in part because it is more visible there, ${ }^{28}$ and in part, possibly, for less pleasant reasons. ${ }^{29}$

Whatever its causes, the heavily disproportionate impact of federal crack penalties on black defendants raises serious concerns of equal protection. Why blacks have borne the brunt of the unusually harsh sentences prescribed for trafficking in crack cocaine ultimately matters less than whether Congress knew blacks would bear this burden. And it turns out Congress did know. It turns out, in fact, the association between blacks and crack cocaine played a

announced its opposition to the proposal. See Reno Backs Strict Sentences for Sellers of Crack Cocaine, N.Y. TIMES, Apr. 16, 1995, at 18.

24. See 1992 AnNuAL. RePORT, supra note 5 , at 88 . The figures for the next twelve months were similar: $88 \%$ of federal crack defendants were black and 4\% were white. See 1993 ANNUAL REPORT, supra note 5, at 152; cf. MCDONALD \& CARLSON, supra note 5, at 90-93 (stating that from January 20, 1989 to June $30,1990,82 \%$ of federal defendants convicted of crack trafficking were black).

25. See 1992 AnNuAl REPORT, supra note 5, at 46, 88. Again, the figures for the next year differed little: $29 \%$ of both powder cocaine defendants and of federal defendants overall were black, while $31 \%$ of powder cocaine defendants and $44 \%$ of federal defendants overall were white. See 1993 ANNUAL REPORT, supra note 5, at 57, 152. (1993).

26. See Elliott Currie, Reckoning: Drugs, the Cities, and the American future 36-123

27. See id. at 123-32; Mark A.R. Kieiman, Against Excess: Drug Policy for Results 299 (1992); Peter Reuter, Robert MacCoun \& Patrick Murphy, Money From Crime: A Study of the Economics of Drug Dealing in Washington, D.C. (1990).

28. See Steven Belenko, Jeffrey Fagan \& Ko-lin Chin, Criminal Justice Responses to Crack, $28 \mathrm{~J}$. Res. Crime \& Deline. 55, 56-57 (1991).

29. See United States v. Clary, 846 F. Supp. 768, 790 (E.D. Mo.) (suggesting that "prosecutors in the federal courts are selectively prosecuting black defendants who were involved with crack, no matter how trivial the amount, and ignoring or diverting whites when they do the same thing"), rev'd on other grounds, 34 F.3d 709 (8th Cir. 1994). I saw no evidence of race affecting charging decisions during my tenure as a federal prosector in Los Angeles. But see United States v. Armstrong, 48 F.3d 1508 (9th Cir. 1995) (en banc) (concluding that "statistical evidence suggesting that blacks are disproportionately charged with federal crack offenses" in Los Angeles provided "a colorable basis for concluding that invidious discrimination may have occurred," and therefore justified a discovery order); Dan Weikel, War on Crack Targets Minorities Over Whites, L.A. Times, May 21, 1995, at A1 (describing allegations that federal crack prosecutions in Los Angeles target black defendants). 
significant role in shaping public and congressional perceptions of drug abuse in 1986.

\section{B. Crack Cocaine and the Politics of 1986}

Crack and powder cocaine are both forms of the same psychoactive alkaloid derived from the leaves of the coca plant. ${ }^{30}$ Cocaine powder is a salt, technically known as cocaine hydrochloride. Crack cocaine-also known as cocaine base or rock cocaine-is a hard, waxy substance, composed of the cocaine alkaloid without the hydrochloride attached. Cocaine powder is easily converted into crack by heating it in water with baking soda; a pound of powder treated in this manner yields roughly a pound of crack. ${ }^{31}$

Cocaine in either form is a powerful, short-acting stimulant. Crack has two properties, though, that make it considerably more dangerous than powder co-

30. See Theo C. Manschreck, M.D., M.P.H., The Treatment of Cocaine Abuse, 64 Psychiatric Q. $183,184-85$ (1993). The checkered history of cocaine use in the United States may warrant a brief digression. Although South American Indians have chewed coca leaves for at least the past thirteen centuries, cocaine was not isolated from the plant until the mid-19th century. John B. Murray, An Overview of Cocaine Use and Abuse, 59 Psychol. REP. 243, 243-44 (1986). The drug was introduced into the United States in the mid-1880s and quickly became something of a fad, its virtues extolled by marketers and medical authorities alike. See Davi T. Courtwright, Dark Paradise: OpIate AddicTION IN AMERTCA BEFORE 1940, at 96 (1982); Murray, supra, at 245-46; Musto, supra note 11, at 44; David F. Musto, America's First Cocaine Epidemic, Wrnson Q., Summer 1989, at 59, 59-60. Parke, Davis \& Co.-the major American manufacturer of cocaine-sold the drug in fifteen forms, "including coca-leaf cigarettes and cheroots, cocaine inhalant, a Coca Cordial, cocaine crystals, and cocaine in solution for hypodermic injection." Musto, supra, at 60 . The company boasted that cocaine "can supply the place of food, make the coward brave, the silent eloquent and . . . render the sufferer insensitive to pain." Quoted in Musto, supra note 11, at 44. Coca Cola began life in 1886 as a "brain tonic" and continued to contain cocaine until 1903. See Murray, supra, at 246.

State and local restrictions on cocaine and other drugs began to appear around the turn of the century, and eventually led to the Harrison Act, ch. 1, 38 Stat. 785 (1914), imposing tight federal control over cocaine, opium, and morphine. See FrIEDMAN, supra note 6, at 355; Musto, supra note 13, at 5468; CourTwright, supra, at $98,103-06$. Cocaine consumption by that time apparently had already started to wane, see Musto, supra, at 62 , and by mid-century use of the drug had "diminished to the

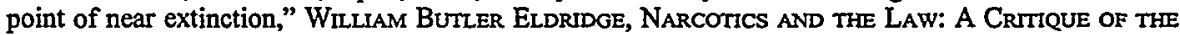
AMERICAN EXPERIment in Narcotic Drug Control 2 (2d ed. rev. 1967); see also Musto, supra note 13 , at 264; Musto, supra note 11, at 45. By the late 1970s, however, cocaine use had begun to rise again, aided perhaps by a degree of historical amnesia about its long-term hazards. See, e.g., KLEIMAN, supra note 27, at 295; Frank H. Gawin, M.D. \& Everett H. Ellingwood, Jr., M.D., Cocaine and Other Stimulants: Actions, Abuse, and Treatment, 318 NEw ENG. J. MED. 1173, 1180 (1988); Kerr, supra note 12 , at B6.

31. See United States v. McMurray, 833 F. Supp. 1454, 1473 \& n.29 (D. Neb. 1993), aff'd, 34 F.3d 1405 (8th Cir. 1994); CuRRIE, supra note 26, at 335; Gawin \& Ellingwood, supra note 30, at 1175. The Anti-Drug Abuse Act uses the term "cocaine base." See 21 U.S.C. \& 841(b)(1)(A)(iii), (B)(iii) (1988 \& Supp. V 1993). This term has created some confusion, stemming in part from the earlier use of the Spanish term base, meaning paste, to refer to a "crude, early-stage product of the refining process of coca leaves." M. Elena Khalsa, M.D., Ph.D., Donalt P. Tashkin, M.D. \& Brian Perrochet, Smoked Cocaine: Patterns of Use and Pulmonary Consequences, 24 J. Psychoactive Drugs 265, 266 (1992); Ronald K. Siegel, Ph.D., Cocaine Smoking, 14 J. Psychoactrve Druas 271, 287 (1982). In the early 1970 s, some American cocaine users began to produce a purified, smokable form of the drug by stripping the cocaine alkaloid from the hydrochloride, generally using a hazardous process involving highly flammable ether. The resulting product was called cocaine base, or more commonly cocaine freebase. See James A. Inciardi, Ph.D., Beyond Cocaine: Basuco, Crack, and Other Coca Products, 14 Conremp. Drug ProBs. 461, 465 (1987). Crack differs from freebase not only because the method used to produce it is simpler and safer, but also because it is generally unpurified-'the residual salt and other impurities and diluents remain present in the consumed substance." Khalsa et al., supra, at 267. 
caine. First, because it is hard and waxy rather than powdery, it is easier to package and to market in small, inexpensive quantities. ${ }^{32}$ Second, and more important, crack is easily smoked; powder cocaine is not, and instead is generally sniffed. ${ }^{33}$ This makes a world of difference, because when cocaine is smoked rather than sniffed, it enters the bloodstream more quickly, provides a briefer, more intense high-and is far more addictive. ${ }^{34}$

Much of the heightened public concern about drugs in 1986, when Congress formulated mandatory minimum sentences for narcotics trafficking, focused on crack cocaine. Crack was first sold in the United States in the early $1980 \mathrm{~s}^{35}$ and began to attract sporadic media attention in 1984 and $1985 .{ }^{36}$ The attention mounted steeply in 1986,37 and by the fall of that year "[t]he cocaineusing 'crack-head' had replaced the heroin-using 'junkie' as the popular image of the menacing drug addict." 38

Crack is an exceptionally harmful drug; the horrendous damage it can do to users, their families, and their communities is all too real. ${ }^{39}$ Still, the popular image of crack in 1986 is worth pausing over, because in certain respects it

32. See KLEmaN, supra note 27, at 297; Inciardi, supra note 31 , at 485 .

33. See KI EIMAN, supra note 27 , at 296 . Technically, even crack is not actually "smoked," because "[r]ather than burning, crack vaporizes and the fumes are inhaled." Inciardi, supra note 31, at 489 n.21.

34. See Kienman, supra note 27, at 296; James F. Jekel, Henry Podlewski, Sandra Dean-Patterson, David F. Allen, Nelson Clarke \& Paul Cartwright, Epidemic Free-Base Cocaine Abuse, 1986 LANCET 459,459 . Not all crack users, however, become compulsive consumers of the drug. See Inciardi, supra note 31, at 484 (reporting that among juvenile crack users studied in Miami, "compulsive users ... represented an extremely small minority"); Yuet W. Cheung, Patricia G. Erickson \& Tammy C. Landau, Experience of Crack Use: Findings From a Community-Based Sample in Toronto, 21 J. DRUG IssuEs 121, 121 (1991) (concluding that "crack use is not necessarily compulsive").

35. See Kreman, supra note 27, at 297; Ansley Hamid, Ph.D., The Developmental Cycle of a Drug Epidemic: The Cocaine Smoking Epidemic of 1981-1991, 24 J. PsYCHOACTIVE DRUGS 337, 338 tbl. 1 (1992).

36. See, e.g., Andy Furillo, South-Central Cocaine Sales Explode into $\$ 25$ 'Rocks,' L.A. TMME, Nov. 25, 1984, § 2, at 1; Jane Gross, A New, Purified Form of Cocaine Causes Alarm as Abuse Increases, N.Y. Tmes, Nov. 29, 1985, at Al.

37. See, e.g., America's Crusade, TME, Sept. 15, 1986, at 60; Joel Brinkley, U.S. Says CocaineRelated Deaths Are Rising, N.Y. Temes, July 11, 1986, at A1; Crack, TmE, June 2, 1986, at 16 (describing crack as "the drug of the moment"); Peter Kerr, Crack Addiction Spreads Among the Middle Class, N.Y. TIMes, June 8, 1986, at A1; Peter Kerr, Drug Treatment in City is Strained by Crack, a Potent New Cocaine, N.Y. TIMEs, May 16, 1986, at Al; Peter Kerr, Opium Dens for the Crack Era, N.Y. TIMES, May 18, 1986, at Al; Peter Kerr, Washington Heights: Cocaine Trade Thrives, N.Y. TmEs, Apr. 1, 1986, at A1; Dody Tsiantar, "Crack" Making Violent Presence Felt in New York: Cheap, Highly Addictive Form of Cocaine is Spreading in Major Cities, Authorities Say, WASH. Post, June 13, 1986, at A3. 48 Hours on Crack Street, a two-hour report on crack broadcast by CBS in September 1986, drew more viewers than any CBS documentary since 1977, see Morgan Gendel, Inside TV, L.A. TIMEs, Sept. 22, 1986 , § 5 (Calendar), at 8, and Congress declared October 1986 "Crack/Cocaine Awareness Month," Pub. L. No. 99-481, 100 Stat. 1224 (1986).

38. KLEMAN, supra note 27 , at 296.

39. See, e.g., CuRRIE, supra note 26, at 182-84 (discussing effects of material crack use on fetal development); Christopher JeNCKs, THE Homeless, $41-48$ (1994) (discussing link between crack use and homelessness); Gawin \& Ellingwood, supra note 30, at 1175-80 (summarizing psychiatric problems associated with cocaine use); James A. Inciardi \& Anne Pottieger, Crack-Cocaine Use and Street Crime, 24 J. DRug Issues 273 (1994) (reporting high correlation between crack use and street crime in Miami); Khalsa et al., supra note 31, at 268-71 (describing pulmonary consequences of cocaine smoking). 
paralleled the popular image of other drugs at earlier points in American history, and those parallels shed some light on the shaping of the 1986 legislation.

Crack is the most recent in a series of drugs that at various times have come to symbolize, to a greater or lesser extent, the entire problem of illicit narcotics in America. A similar role was played by smokable opium in the late nineteenth century, powder cocaine in the early twentieth century, marijuana in the $1920 \mathrm{~s}$ and $1930 \mathrm{~s}$, and heroin in the $1950 \mathrm{~s} .{ }^{40}$ In each case, the drug of primary concern was strongly associated in the white public mind with a particular racial minority: opium in the late nineteenth century with Chinese immigrants on the west coast, ${ }^{41}$ powder cocaine in the early twentieth century with southern blacks, ${ }^{42}$ marijuana in the 1920 s and 1930 s with Mexican Americans in the southwest, ${ }^{43}$ and heroin in the 1950 s with urban blacks. ${ }^{44}$ In each case, moreover, much of the public anxiety about the feared narcotic stemmed from a concern that use of the drug was spreading beyond the confines of the minority group with which it traditionally had been associated. ${ }^{45}$

40. See H. Wayne Morgan, Drugs in America: A Social History, 1800-1980, at 29-43, 14548 (1981); Musto, supra note 13, at 1-8; Musto, supra note 11, at 45-46.

41. See FrIedMan, supra note 6, at 137-38; Morgan, supra note 40, at 35-37; Musto, supra note 13, at 3-4, 43; Elmer Clarence Sandmeyer, The Anti-Chinese Movement in California 34 (1939).

42. By the early years of the 20th century, "[t]he association of cocaine with the southern Negro became a cliché," MUSTo, supra note 13, at $282 \mathrm{n.15}$, and proponents of tightened drug laws regularly played on white "fear of the cocainized black." Id. at 7, 43-44. "Negro cocaine fiends" were regularly blamed for attacks on white women and other crimes, and the diug was rumored not only to stimulate sexual assault, but also to increase blacks' strength, to improve their pistol marksmanship, and to render them impervious to .32 caliber bullets. Id. at 7, 43-44, $282 \mathrm{n} .15$; see also MorgAN, supra note 40 , at 92-93. A State Department report to Congress in 1910 noted that "[i]t has been authoritatively stated that cocaine is often the direct incentive to the crime of rape by negroes of the South and other sections of the country." Hamilton Wright, Report of the International Opium Commission and on the Opium Problem as Seen within the United States and Its Possessions, in OpIUM Problem: Message from the President of the UNITEd States, S. Doc. No. 377, 61st Cong., 2d Sess. 50 (1910).

The extent to which blacks actually used cocaine in this period is open to dispute. Compare Musto, supra note 13,'at 8 (questioning claims of widespread use of cocaine by blacks) with CourTWRIGHr, supra note 30 , at $97,197 \mathrm{n} .79,199 \mathrm{n} .80$ (1982) (concluding that "cocaine was relatively popular in black communities").

43. See Richard J. Bonnie \& Charles H. Whtrebread II, The Mardfuana Conviction: A History of Marihuana Prohibition in the Untted States 30, 45-47, 70-77 (1974); Jerome L. Himmelstein, The Strange Career of Marihuana: Politics and Ideology of Drug Control in AMERICA 50-54 (1983); MORGAN, supra note 40, at 138-39; Musto, supra note 13, at 219, 358 n.18; David F. Musto, M.D., The Marihuana Tax Act of 1937, ARchives Gen. PsYchIATRY, Feb. 1972, at 101, 103-04. An earlier marihuana scare in Califomia seems to have been linked to concern, particularly in San Francisco, about immigrants from the Indian subcontinent. See BonNIE \& WhITEBread, supra, at 41 ; Musto, supra, at 102.

44. See Morgan, supra note 40 , at 145,153 . The hallucinogen scare of the 1960 s departed somewhat from this general pattern: "the hippie became the racial image of the 1960s drug debate." Id. at 165.

45. Late 19th century restrictions on opium smoking were apparently spurred in large part by fears that the practice had spread, or was about to spread, to upper-class whites. See CoURTWRIGHr, supra note 30, at 78-83. Indeed, initial enforcement of anti-opium laws selectively focused on dens patronized by whites. See id. at 78 ; SANDMEYER, supra note 41 , at 34 . Similarly, fear that drug use was spreading "into the higher classes" appears to have underlaid much of the cocaine, marijuana, and heroin scares later in the century. See BONnIE \& WhITEBREAD, supra note 43, at 41, 52; MORGAN, supra note 40, at 140,153 . Conversely, many blacks have long complained about white indifference to drug use in the ghetto: "White people have never been anxious to fight a problem that they perceive to be . ... an allblack problem. ... It was only when it got to suburbia that it became a joint problem, a white problem, a 
To a notable extent, the crack scare of 1986 followed a similar pattern. ${ }^{46}$ Whites strongly associated crack with the same minority group they linked with heroin-inner city blacks-and there was widespread fear that use of the drug was expanding beyond the ghetto into suburbia. The association between crack and urban blacks was twofold. Not only did crack do most of its damage in the ghetto, or at least most of its visible damage, 47 but crack vendors were widely understood to be, for the most part, black men. ${ }^{48}$ This second association gave a particular tinge to media reports that crack was entering "middle class" neighborhoods. For example, a relatively early series of articles about crack in the Palm Beach Post and Evening Times, commended and inserted into the Congressional Record by Senator Lawton Chiles, noted that "[l]ess than a block from where unsuspecting white retirees play tennis, bands of young black men push their rocks on passing motorists, interested or not." 49 And when a Newsweek cover story, also reprinted and applauded in the Congressional Record, warned of "ominous signs that crack and rock dealers are expanding well beyond the inner city," 50 it accompanied that warning with photographs of two crack dealers, both black males, and offered the following description of a third:

national problem." Howard Kunz, Drug Plague a Racist Conspiracy? L.A. Times, Jan. 2, 1990, at E1 (quoting NAACP Executive Director Benjamin L. Hooks); see also David Treadwell, Blaming a Hidden Enemy, L.A. Tnmes, Sept. 17, 1990, at Al; cf. Thomas Byrne Edsall with Mary D. Edsall, Chatn REACTION 237 (1991) (reporting "widely held view" among blacks "that the white power structure has permitted, if not actually encouraged, the flow of crack cocaine into black neighborhoods'); William Komblum, Dug Legalization and the Minority Poor, 69 MnBaNk Q. 415, 422 (1991) (arguing that illegal drug markets in fact became concentrated in minority communities through "the time-honored practice of ghetto containment of deviance").

46. I am hardly the first to make this observation. See, e.g., United States v. Clary, 846 F. Supp. 768, 774-78 (E.D. Mo.), rev'd, 34 F.3d 709 (8th Cir. 1994); United States v. Walls, 841 F. Supp. 24, 2830 (D.D.C. 1994).

47. The very visibility of crack in the inner city galled some observers. See, e.g., 132 CoNG. REC. 26,454 (1986) (remarks of Sen. Moynihan) ("The fact that drug sales and use are taking place more frequently in public, on our streets, is the most appalling single thing of the present crisis."); Belenko et al., supra note 28, at 57 ("The shift ... to a street-level strategy was fueled in large part by community outrage about open-air drug markets on the Lower East Side of Manhattan, which intensified with the spread of street sales of crack.').

48. The television documentary, 48 Hours on Crack Street, illustrated, perhaps inadvertently, the pervasiveness of this understanding. Told by a reporter that a man had been selling crack nearby, a police officer asked, "[C]an you give me a description of him? Male? Black? How tall?" 48 Hours on Crack Street 33 (CBS television broadcast, Sept. 19, 1986) (transcript on file with author); see also, e.g., Crack, Tma, June 2, 1986, at 16-17 ("The drug is most popular in the inner city; a recent survey by the cocaine hotline indicates that ... more than half the nation's so-called crackheads are black.").

49. 132 CoNG. REC. 8291,8292 (1986) (reprinting article entitled "It's Cheap, It's Available and It's Ravaging Society"). The same article reported that "[m]ost of the dealers, as with past drug trends, are black or Hispanic. . . . Haitians also comprise a large number of those selling cocaine rocks ... Whites rarely sell the cocaine rocks." Id. A later article in the series observed that "[f]or the growing numbers of the white middle class who have become hooked on cocaine rock, buying the drug can be like stepping into a foreign culture." Id. at 8294 (reprinting article entitled "Rock Sellers Neither Shy nor Unavailable"). Indeed, the paper noted, "several" crack houses raided by police contained "icons of Santieria, a Caribbean folk religion that mixes Catholicism and traditional African beliefs." Id.

50. Crack and Crime, supra note 22, at 16,20. Senator Paula Hawkins inserted the Newsweek article into the Congressional Record on June 9, 1986, and "commend[ed]" the article to her colleagues. See 132 CoNG. REC. 13026 (1986). 
One of the boldest dealers on the street is 'Eare,' a big-shouldered Trinidadian wearing gold chains and a diamond-studded bracelet with his name engraved in it. . . . Eare operates as brazenly as a three-card-monte dealer, waving fistfuls of bills around as he deals his drugs at the corner of $42 \mathrm{nd}$ and Seventh. ${ }^{51}$

What was coming was not just a drug-it was a black drug, sold by black men. That was not the only reason crack was frightening to white Americans, but it was one of the reasons. ${ }^{52}$

It was also an important part of the atmosphere in which Congress fashioned the current mandatory minimum sentences for drug trafficking. The first of many bills proposing heightened penalties for crack offenses was introduced on June 20,1986.53 Its sponsors took note of the Newsweek article and a New York Times story reporting the spread of crack use to the middle class. ${ }^{54}$ The following months were marked by a sharp increase in congressional attention to illegal drugs in general and crack in particular, and by a rush to pass dramatic drug legislation before the midterm elections in November. ${ }^{55}$ They were also marked by repeated expressions of congressional concern that the use of drugs generally, and the use of crack in particular, was expanding beyond the ghetto. 56

51. Crack and Crime, supra note 22, at 18.

52. See generally George M. Fredrickson, The Black Image in the White Mind: The Debate on Afro-American Character and Destiny, 1817-1914, at 275-82 (1971) (describing origins of the image of the black brute); ANDREW HACKER, Two NATIONS 179-98 (1992) (discussing white dread of black crime). Another reason, of course, was that crack was often perceived as a foreign drug, sold at least initially by Caribbean blacks. See, e.g., "Crack" Cocaine: Hearing Before the Permanent Subcomm. on Investigations of the Senate Comm. on Governmental Affairs, 99th Cong., 2d Sess. 58 (1986) (testimony of Sheriff James Adams, Sumter County, Fla.) ("[I]t is believed the Haitian community in our county is responsible for a large portion of the rock cocaine.") [hereinafter Crack Cocaine Hearing]; see also note 49 supra; note 58 infra.

53. S. 2580,99 th Cong., $2 d$ Sess. (1986).

54. See 132 CONG. REC. 14,822-23 (1986).

55. See Dorothy Collin, Politicians Latch Onto Drug Issue, Chr. Tris., Aug. 4, 1986, § 1, at 1. The Democratic leadership of the House of Representatives held a press conference on July 23 to call for comprehensive drug legislation by the fall. See Reginald Stuart, O'Neill Proposes Congress Mount Attack on Drugs, N.Y. Times, July 24, 1986, at Al. Five days later the White House announced its own campaign against drug abuse. See Bemard Weinraub, White House Says Reagan Plans New Campaign Against Drug Abuse, N.Y. Times, July 29, 1986, at AI.

Eric Sterling, then the House Judiciary Committee's principal staffer for drug enforcement issues, has since described the development of the 1986 legislation as "extraordinary," because of "the intensity of the climate of legislative haste." He explained, "The careful deliberative practices of the Congress were set aside for the drug bill.... The development of this bill was the sole instance during more than nine years with the Judiciary Committee that $I$ did not see the usual procedure upon introduced bills followed." Hearings, supra note 17, at 2-3 (testimony of Eric E. Sterling). Sterling noted that "[i]t was the fearful image of crack in the public consciousness that drove the legislative package." Id. at 4.

The extraordinary attention focussed on the drug issue, and the extraordinary haste with which drug legislation was fashioned, did not go entirely unnoticed in the congressional debates. See, e.g., 132 CoNG. Rec. 22670 (1986) (remarks of Rep. Roybal) ("It seems that drug abuse has become the hot topic of 1986."); id. at 26,434 (remarks of Sen. Dole) ("I have been reading editorials saying we are rushing a judgment on the drug bill, and to some extent they are probably correct."); id. at 26,462 (remarks of Sen. Mathias) ("Very candidly, none of us has had an adequate opportunity to study this enormous package."); id. at 27,166 (remarks of Sen Wiecker) ("This is great politics ... this drug bill."); id. at 27,193 (remarks of Sen. Byrd) ("[D]rug stories are the 'rage' in the media right now.").

56. See, e.g., 132 Cong. REC. 26,458 (1986) (remarks of Sen. Heflin) (the "war" against "the supplier, pusher and peddler of illegal drugs" was "once fought only in urban America, but, increasingly, there are daily skirmishes on country roads, on remote rural routes, and in the tree-lined streets of 
This was not the only fear voiced in Congress. Some members stressed the particular dangers that crack posed for black communities; indeed, part of the concern about crack was that its marketing put cocaine, previously a pricey drug for the rich, within reach of the poor. 57 But the concern that resonated most strongly was not that crack and other narcotics were tightening their hold on the inner city -it was that they were spreading outward from their former confines. ${ }^{58}$ Public and congressional concern about cocaine abuse was sharply heightened, for example, by the cocaine-related deaths in late June 1986 of two black athletes, Len Bias and Don Rogers. ${ }^{59}$ For Congress, though, as for most white Americans, what the deaths of Bias and Rogers dramatized was not that drug abuse posed special threats for minority communities, but that drug abuse threatened everyone. ${ }^{60}$

small towns and villages"; "the battleground has moved into middle-class neighborhoods, into glass skyscrapers, and even into school playgrounds"); $i d$. at 19,248 (remarks of Sen. Rockefeller) ("Drug abuse among young people has spread to all parts of the country and has entered every segment of society.... '[C]rack' has made its way to small communities as well as the large cities."); $i d$. at 22,697 (remarks of Rep. Roukema) (" 'crack houses' . . . are no longer confined to the cities"); id. at H6512 (daily ed. Sept. 10, 1986) (remarks of Rep. Rowland) ("Ten years ago the perception of drug abuse was of a heroin addict in the alleys of our urban areas. ... [W] hat we have seen in the past 2 to 3 years has been an acceptance of cocaine use crisscrossing all age and social and economic barriers, and now in 1986 we see the faddist acceptance of the abuse of crack."); Stuart, supra note 55, at Al (quoting House Speaker Thomas O'Neill's warning that '[d]rug abuse is no longer a problem for a few localities or a few communities to handle"); see also United States v. Clary, 34 F.3d 709, 714 (8th Cir. 1994) (quoting testimony by Eric Sterling that Congress feared the "problem in the inner cities ... was about to explode into the white part of the country').

57. See, e.g., 132 Cong. REC. 8290 (1986) (remarks of Sen. Chiles) (" 'Rock' or 'crack' cocaine is more dangerous and widespread than other drug forms because it is cheaper and available to a whole new class of people who cannot afford other drugs, including young people."); $i d$. at 22,667 (remarks of Rep. Traficant) ("Cocaine is no longer a drug of the affiuent. ... [c]rack can be obtained for as little as $\$ 10$ which makes it accessible to anyone.").

58. Congressional concern over the spread of drug abuse to middle-class neighborhoods was accompanied and heightened by a tendency to view illegal narcotics as a foreign threat, alien to American society. See, e.g., 132 CONG. REC. 8289 (1986) (remarks of Sen. Chiles) (characterizing illegal narcotics as "insidious invaders" and a "form of terrorism," and describing drug dealers as "people, who, while they may claim American citizenship, are nothing more than mercenaries without either country or conscience'); $c f$. Joel Brinkley, Meese Links Drugs and Illegal Aliens, N.Y. Times, Sept. 18, 1986, at B13 (quoting then Attomey General Meese's statement that "[o]ne of the best ways to frustrate the flow of drugs into this country is to stem the flow of illegal aliens across our southern border"). Military metaphors became routine. See, e.g., 132 CoNG. REC. 22,659 (1986) (remarks of Rep. Wright) ("It is time to declare an all-out war, to mobilize our forces . . . in a total coordinated assault upon this menace"); id. at 22,664 (remarks of Rep. Lungren) ("This is a battle that America cannot afford to lose."); id. at 22,698 (remarks of Rep. Torres) ("It is our duty as lawmakers to fight the war on drugs on every front."); id. at 22,703 (remarks of Rep. McCollum) ("[W]e cannot lose sight of the fact that it is a war."). In these respects, too, the 1986 debates echoed aspects of earlier American discussions of drug abuse. See, e.g., Musto, supra note 13, at 247-48, 279 n.3. As in earlier periods, blaming other countries for American drug abuse in 1986 "harmonized with the ascription of drug use to ethnic minorities. Both the external cause and the internal locus could be dismissed as un-American." Id. at 248.

59. See, e.g., 132 CoNG. REc. 19,249 (1986) (remarks of Sen. Leahy) ("The country was shaken recently when cocaine killed two talented young athletes-Len Bias of the University of Maryland and Don Rogers of the Cleveland Browns."); id. at 22,660 (remarks of Rep. Michel) ("The death of basketball star Len Bias shocked us into action.").

60. See, for example, the remarks of Rep. Florio:

"[L]et us do away with the common perception that drug abuse is a problem of the inner city, the ghetto, the public housing projects. It can be found in our more affiuent schools and we have fast become aware of the damage it causes as promising young athletes, such as Len Bias, fall victim to the horrors of drug abuse." 
Alarmed by a perceived explosion of crack use ${ }^{61}$ and, no doubt, by the impending midterm elections, members of Congress engaged in a kind of partisan bidding war over the penalties for crack trafficking. ${ }^{62}$ As the elections drew closer, the difference between the mandatory penalties proposed for powder cocaine and those proposed for crack tended to widen. At the end of July, for example, Senator Paula Hawkins, arguing that "logic and conviction would dictate an attack on crack through an attack on cocaine itself," called for stiff mandatory sentences that did not distinguish between crack and powder. ${ }^{63}$ Two weeks later, though, she joined Senator Alfonse D'Amato in proposing mandatory sentences that treated twenty-five grams of crack the same as fivehundred grams-twenty times as much-of powder cocaine. ${ }^{64}$ The 20:1 ratio also appeared in the legislative packages proposed in September by the Reagan Administration and the Republican Senate leadership. ${ }^{65}$ Earlier that same month, however, the Democratic leadership in the House of Representatives introduced an omnibus drug bill employing a ratio of 50:1.66 And the day after that bill was introduced, the Senate Democratic leadership put forward its own drug bill, containing the 100:1 ratio ultimately signed into law. ${ }^{67}$

132 Cong. REc. H6578 (daily ed. Sept. 10, 1986).

61. In reality, and contrary to popular perception in 1986, "researchers were finding crack to be, not a national epidemic, but a phenomenon isolated to the inner cities of less than a dozen urban areas." Inciardi, supra note 31, at 482. Indeed, in late August 1986 the Drug Enforcement Administration concluded that "[w] ith multikilogram quantities of cocaine hydrochloride available and with snorting continuing to be the primary route of cocaine administration, crack presently appears to be a secondary rather than primary problem in most areas." Id. (quoting STRATEGIC INTELLIGENCE SECTION, DRUG Enforcement adminstration, Special Report: The Crack Situation in the United States (1986)). Subsequent surveys have indicated that "crack never caught on too well in the general population, and where it did, usage rates began to decline at the close of the 1980s." JAMES A. INCLARDI, Dorothy Lockwood \& Anne E. Pottieger, Women and Crack-Cocane 11 (1993).

62. And, to a lesser extent, over the penalties for other drugs. Eric Sterling has described the manner in which the sentences were determined as "like an auction house. ... It was this frenzied, panic atmosphere-I'll see you five years and raise your five years. It was the crassest political poker game." Michael Isikoff \& Tracy Thompson, Getting Too Tough on Drugs: Draconian Sentences Hurt Small Offenders More Than Kingpins, Wash. Posr, Nov. 4, 1990, at C1, C2 (quoting Sterling).

63. 132 Cong. Rec. 17,918 (1986). Senator Hawkins' bill, S. 2697, would have imposed a 20year mandatory sentence for manufacturing or importing a kilogram or more of cocaine, and a 15-year mandatory sentence for importing any lesser amount. On the Senate floor, Hawkins derisively acknowledged the political realities that made her approach impractical: "I realize that attacking crack is much more palatable politically to the drug culture and those many so-called recreational users of cocaine who might look down on 'crack' users." Id.

64. S. 2787, introduced by D'Amato and Hawkins, provided for a five-year mandatory sentence for a first offense involving 500 grams of powder cocaine or 25 grams of crack.

65. See S. 2849 , 99th Cong., 2d Sess. $§ 502$, (Sept. 23, 1986) (administration bill); S. 2850, 99th Cong., 2d Sess. $\$ 1512$, (Sept. 23, 1986) (Republican leadership bill). Like S. 2787, these later bills imposed a mandatory minimum sentence of five years for a first offense involving 500 grams of cocaine powder or 25 grams of crack.

66. See H.R. 5484, 99th Cong., 2d Sess., $§ 608$ (1986) (introduced Sept. 10, 1986). The House Democratic bill called for a five-year mandatory minimum sentence for defendants convicted of trafficking in a kilogram of cocaine powder or 20 grams of crack, and 10-year mandatory minimum sentence for those convicted of trafficking in five kilograms of cocaine powder or 100 grams of crack. The same provisions had been contained in an earlier House bill introduced on August 12. See H.R. 5394, 99th Cong., 2d Sess., §§ 101-02 (1986).

67. S. 2798, 99th Cong., 2d Sess. § 222 (1986). The 100:1 ratio appeared earlier in the bill introduced by Senator D'Amato and Senator Mattingly on June 20,1986. That bill, however, contained no mandatory minimum sentences; it simply would have made defendants caught with one gram of crack or 
That ratio, as previously noted, is a statutory anomaly. Unlike most of the other mandatory minimum provisions in the Anti-Drug Abuse Act, the quantity thresholds for crack are not tied to estimates of the amount of the drug that "kingpins" or "middle level dealers" are likely to possess; as Congress appears to have recognized, "kingpins" and "middle level dealers" are not likely to have crack at all. ${ }^{68}$ The low quantity thresholds for crack thus depart dramatically from the overall statutory scheme. The extent of the departure, moreover was completely arbitrary. 69 The legislative history offers no explanation for the selection of a ratio of $100: 1$ instead of $1,000,000: 1$ or $10: 1^{70}$ — save that 100:1 was the highest ratio proposed.

100 grams of cocaine eligible, within the discretion of the sentencing judge, for any sentence up to the then-maximum penalties for federal narcotics offenses. See S. 2580, 99th Cong., 2d Sess. (1986)

68. See notes 21-23 supra.

69. Former House staffer Eric Sterling has testified that the 50:1 ratio in the Subcommittee's bill "was arbitrarily doubled simply to symbolize redoubled congressional seriousness," and that the 100:1 ratio "reflects no actual calculation of the relative harmfulness to society or an individual of a given number of doses of an illegal drug." Hearings, supra note 17, at 4,6 (testimony of Eric E. Sterling). Dr. Robert Byck, who testified about crack before Congress in 1986, has noted that the 100:1 ratio "is arbitrary ... It neither makes sense nor doesn't make sense. It's just a number." Newton, supra note 23, at A20 (quoting Byck).

Dr. Byck testified at the single, half-day hearing Congress held on the crack problem in 1986. The issue of mandatory sentences was raised only briefly, at the end of the hearing. Two law enforcement officers familiar with crack were asked whether they believed mandatory minimum sentences would deter distribution of the drug. One officer said he could not "honestly answer that," Crack Cocaine Hearing, supra note 52, at 65 (testimony of Deputy Inspector Martin O'Boyle, N.Y.P.D.), and the other recommended a mandatory minimum sentence of one year, id. (testimony of Sheriff James Adams, Sumter County, Fla.).

70. Congress did use a ratio of 10:1 in establishing the quantity thresholds for the subject of the other major drug scare of 1985 and 1986: fentanyl analogs of heroin, the most notorious of the so-called "designer drugs." Designer drugs are synthetic, highly potent versions of traditional, botanically-derived narcotics. Like crack, designer drugs were feared to be "the drug wave of the future." Designer Drugs, 1985: Hearing Before the Subcomm. on Children, Family, Drugs and Alcoholism of the Senate Comm. on Labor and Human Resources, 99th Cong., 1st Sess. 2 (1985) [hereinafter Designer Drug Hearing] (statement of Sen. Hawkins); see also, e.g., id. at 10 (statement of Sen. Grassley) ("The phenomenon we have on our hands is a time bomb. Its consequences and dimensions could not be more frightening."); 132 CoNG. REC. 22,915 (1986) (remarks of Sen. Lungren) ("designer drugs are the new epidemic of drugs in this country"); id. at 22,697 (remarks of Rep. Roukema) ("new "high-tech' drugs threaten even the first-time casual user with life-threatening addition or instant death"); The Next High, TIME, Sept. 15, 1986, at 68 ("Many experts fear that [designer drugs] may form the next drug epidemic."). Also like crack, designer drugs were not thought to be distributed through networks of "kingpins" and "middle-level dealers." See Designer Drug Hearing, supra, at 2 (statement of Sen. Hawkins) ("the designer drug operation is still in the hands of smail entrepreneurs"); id. at 10 (statement of Sen. Grassley) ("What used to be the province of powerful international drug syndicates, is now becoming a cottage industry."). Yet, despite the fact that they were understood to be thousands of times more potent than heroin, see, e.g., H.R. REP. No. 848, 99th Cong., 2d Sess. 4 (1986); 132 CoNG. REc. 26,447 (1986) (remarks of Sen. Chiles), the quantity thresholds for most fentanyl analogs were set at one-tenth those for heroin-and double those for crack. Compare 21 U.S.C. § 841(b)(1)(A)(i), (B)(i) (1988 \& Supp.V 1993) (mandatory minimum sentences of 10 years for a kilogram, and five years for 100 grams, of "mixture or substance" containing heroin) (1988 \& Supp. V 1993) with id. \& 841(b)(1)(A)(vi), (B)(vi) (mandatory minimum sentences of 10 years for 100 grams, and five years for 10 grams, of "mixture or substance" containing certain fentanyl analogs) (1988 \& Supp. V 1993). One possible explanation is that unlike crack, linked from the start in the public mind with inner city blacks, fentanyl analogs first surfaced in Orange County, California, and at least initially were perceived as "a suburbia drug." Designer Drug Hearing, supra, at 11 (statement of Robert J. Roberton, Chief, California Department of Alcohol and Drug Programs, Division of Drug Programs). 


\section{Equal Protection Concerns}

Arbitrary laws are not necessarily unconstitutional, unfair, or even undesirable. Some degree of arbitrariness is inherent in almost any legislation-lines need to be drawn somewhere. But the arbitrary nature of the 100:1 ratio between the quantities of powder cocaine and crack that trigger federal mandatory sentences, combined with the dramatically disproportionate impact federal crack penalties have on black defendants, and the striking manner in which those penalties depart from the overall logic of federal narcotics sentences, does raise serious concerns of equal protection.

Or at least, I am about to suggest, it should. For reasons to be discussed later, equal protection challenges to the federal crack sentences in fact have failed miserably in court. That outcome, we will see, was drearily predictable to anyone familiar with the equal protection rules developed in the last several decades by the Supreme Court. Before we look at the problem through the Court's doctrinal spectacles, though, it is worth examining the crack sentences through wider lenses, and observing the concerns the sentences raise for the underlying goals of equal protection.

The nature of those goals, of course, is a matter of great dispute. A long and rich debate continues over whether equal protection should principally be, to put it crudely, a matter of process - treating people equally - or of resultsmaking people equal. ${ }^{71}$ Nor is there broad agreement, among those who focus on process, about what constitutes equal treatment, ${ }^{72}$ or, among those who look to results, about what making people equal actually means. ${ }^{73}$

71. See, e.g., Kimberlé Williams Crenshaw, Race, Reform, and Retrenchment: Transformation and Legitimation in Antidiscrimination Law, 101 HARv. L. Rev. 1331, 1341-46 (1988) (contrasting "equality as a process" and "equality as a result"); Randall L. Kennedy, McCleskey v. Kemp: Race, Capital Punishment, and the Supreme Court, 101 Harv. L. REv. 1388, 1424 (1988) (calling for a perspective that "looks beyond the process producing inequality ... to the objective indicia of inequality itself").

72. Compare, e.g., Kenneth L. Karst, Foreword: Equal Citizenship Under the Fourteenth Amendment, 91 HARV. L. REV. 1, 4 (1977) (arguing that "the substantive core" of equal protection "is a principle of equal citizenship, which presumptively guarantees to each individual the right to be treated by the organized society as a respected, responsible, and participating member') and RONALD DwORKN, TARING RIGHTS SERIousLY 198-99 (1977) (defining "political equality" as the idea "that the weaker members of a political community are entitled to the same concern and respect of their government as the more powerful members have secured for themselves") with Cass R. Sunstein, Public Values, Private Interests, and the Equal Protection Clause, 1982 Sur. CT. REv. 127, 128 (reading the Equal Protection Clause "to prohibit unprincipled distributions of resources and opportunities," i.e., distributions that "are not an effort to serve a public value, but reflect the view that it is intrinsically desirable to treat one person better than another") and Hobson v. Hansen, 269 F. Supp. 401,497 (D.D.C. 1967) (suggesting that equal protection bars any "government action which without justification imposes unequal burdens or awards unequal benefits").

73. Compare, e.g., Owen M. Fiss, Groups and the Equal Protection Clause, 5 PHIL. \& PuB. AfF. 107,157 (1976) (arguing that equal protection prohibits laws that reinforce "the subordinate position of a specially disadvantaged group") with Laurence $\mathrm{H}$. Tribe, The Puzzling Persistence of Process-Based Constitutional Theories, 89 YALE L.J. 1063, 1077 (1980) (suggesting that "[t]he crux of any determination that a law unjustly discriminates against a group ... [is] that the law is part of a pattern that denies those subject to it a meaningful opportunity to realize their humanity").

Nor do these differences exhaust the debate, because what kind of equality the law should protect is not the same question as how that protection should be provided. Kenneth Karst, for example, argues that courts should test for violations of his "equal citizenship" principle by "insist[ing] on a showing of 
Attempting a resolution of any of these issues is beyond the scope of this essay. Indeed, I will suggest later that it is a mistake to try to reach agreement on the precise nature of equal protection in the abstract. Let us therefore provisionally adopt one particular view of what equal protection should be about: the "process theory" generally traced to footnote four of Justice Stone's opinion for the Supreme Court in United States $v$. Carolene Products, ${ }^{74}$ and most fully articulated in the writings of Paul Brest and John Hart Ely. ${ }^{75}$ Under this view, the purpose of equal protection law is to correct for a certain marginal deficiency of majoritarian democracy: the danger that the majority, because it cares less about a minority's welfare than about its own, will award members of the minority fewer benefits, or impose on them disproportionate burdens. ${ }^{76}$

I pick this view for two reasons. First, it has been remarkably influential. Justice Stone's footnote, and the elaborate glosses by Brest and Ely, have shaped much of equal protection debate over the past two decades, both among the justices ${ }^{77}$ and among commentators. ${ }^{78}$ Second, and more important, process theory of the Carolene Products variety is at this point a kind of lowest common denominator of approaches to equal protection: pretty much everyone agrees that equal protection should guard against prejudiced decisions to disadvantage members of "discrete and insular minorities,"79 although many people think it should also do more. Some of the justices, for example, part company with Brest and Ely by reasoning that equal protection bars much overt discrimi-

justification when the government's behavior intensifies a group's subordination." KENNETH L. KARST, Belonging to AMERICA 158 (1989); see also Karst, supra note 72, at 50-52 \& n.287. Conversely, Randall Kennedy has recently suggested that the best way for courts to test for laws that truly burden blacks "as a class" is to focus on the presence or absence of discriminatory purpose. Randall Kennedy, The State, Criminal Law, and Racial Discrimination: A Comment, 107 HARv. L. Rev. 1255, 1272-74 (1994).

74. 304 U.S. 144, 152 (1938).

75. See John Hart Ely, Democracy and Distrust $135-79$ (1980); Paul Brest, Foreword: In Defense of the Antidiscrimination Principle, 90 HARv. L. Rev. 1 (1976). Brest and Ely differ on many particulars, but for present purposes their differences are less important than what they share.

76. Justice Stone's famous footnote in Carolene Products suggestively declined to inquire "whether prejudice against discrete and insular minorities may be a special condition, which tends seriously to curtail the operation of those political processes ordinarily to be relied upon to protect minorities, and which may call for a correspondingly more searching judicial inquiry." 304 U.S. 144, 152 n.4 (1938). Brest and Ely have reasoned that such prejudice is indeed a "special condition," and that equal protection law should guard against failures by the majority to provide minority-group members with "equal concern and respect," ELy, supra note 75, at 82, 170 (quoting DworkIN, supra note 72, at 180), or with "the same sympathy and care," Brest, supra note 75, at 8, given to members of the majority. Ely has tied this principle to a broader thesis, also drawn from Carolene Products, that "constitutional law appropriately exists for those situations where representative government cannot be trusted," ELy, supra note 75 , at 183, and that judicial review should therefore "concern itself only with questions of participation, and not with the substantive merits of the political choice under attack," $i d$. at 181.

77. See, e.g., United States R.R. Retirement Bd. v. Fritz, 449 U.S. 166, 179 n.12 (1980); Personnel Adm'r v. Feeney, 442 U.S. 256, 272 (1979).

78. See e.g., Bruce A. Ackerman, Beyond Carolene Products, 98 HARv. L. Rev. 713, 716 \& nn.5 \& 6 (1985); Daniel R. Ortiz, The Myth of Intent in Equal Protection, 41 STAN. L. Rev. 1105, 1105-06 \& n.7, 1108-09 (1989).

79. Carolene Products, 304 U.S. at 153 n.4. 
nation in favor of racial minorities, ${ }^{80}$ but they would not defend, at least not in theory, a law that imposed particular hardship on blacks because of white prejudice, even if the law avoided any overt racial classification. ${ }^{81}$ Conversely, many academic critics argue that certain laws unduly burdening disadvantaged groups should be struck down regardless why they were passed; for these critics as well, the laws found objectionable by Brest and Ely constitute a special case of what equal protection prohibits. ${ }^{82}$ Thus, although many courts and commentators believe that the Carolene Products approach is too limited, and although there is broad disagreement about how it should be expanded, virtually no one thinks it should be contracted, or that the problems it identifies are illusory or exaggerated. Few defend laws acknowledged to have been shaped by racism.

In this respect, at least, drug laws are no different. Randall Kennedy and Kate Stith, for example, have suggested that heightened penalties for crack trafficking may actually help blacks as a class, because black communities have been especially ravaged by the drug. ${ }^{83}$ Indeed, Stith has noted that such penalties could be viewed as a "laudatory attempt" to provide black communities with "enhanced protection." 84 Now, there is good reason to doubt the salutary effects on black communities of subjecting a disproportionate number of black men to long prison sentences. ${ }^{85}$ But suppose Kennedy and Stith are right about the social consequences of the federal crack sentences. Suppose further that the extraordinary severity of the crack sentences, as a matter of historical fact, is directly attributable to racial prejudice against the black defendants who wind up serving them. Few would support the sentences then-not even, one suspects, Kennedy and Stith. ${ }^{86}$

80. Compare, e.g., Adarand Constructors, Inc. v. Pena, 63 U.S.L.W. 4523 (June 12, 1995) and Shaw v. Reno, 113 S. Ct. 2816 (1993) with ELY, supra note 75, at 170-72 and Brest, supra note 75, at 16-22.

81. See e.g., Hunter v. Underwood, 471 U.S. 222 (1985).

82. See, e.g., KARsT, supra note 73, at 158-67; Ackerman, supra note 78 at 718-22; Paul R. Dimond, The Anti-Caste Principle-Toward a Constitutional Standard for Review of Race Cases, 30 WAYNE L. REv. 1, 5 (1983); Fiss, supra note 73; Tribe, supra note 73, at 1077-80.

83. See Kennedy, supra note 73, at 1267-69; Kate Stith, The Government Interest in Criminal Law: Whose Interest Is It, Anyway?, in Public Values IN Constitutional Law 137, 153 (Stephen E. Gottlieb ed., 1993); cf. United States v. McMurray, 833 F. Supp. 1454, 1467 (D. Neb. 1993), aff'd, 34 F.3d 1405 (8th Cir. 1994) (noting that "the social costs of 'disproportionate' prosecution of African Americans might be deemed acceptable precisely so that other poor people, including poor blacks, are afforded some protection from the scourge of 'crack' ").

84. Stith, supra note 83 , at 153.

85. See, e.g., Marc Mauer, The Sentencing Project, Young Black Men and the Crmmal Justice System: A Growing NAtional Problem 4 (1990) (waming that escalating rates of incarceration "risk the possibility of writing off an entire generation of Black men from having the opportunity to lead productive lives in our society"); Matthew F. Leitman, A Proposed Standard of Equal Protection Review for Classifications Within the Criminal Justice System That Have a Racially Disparate Impact: A Case Study of the Federal Sentencing Guidelines' Classification Between Crack and Powder Cocaine, 25 U. ToL. L. Rev. 215, 230-32 (1994) (arguing that harsh crack sentences, in particular, reinforce the subordination of black communities); Steve Rickman, The Impact of the Prison System on the African Community, 34 HowARD L.J. 524, 526 (1991) (suggesting that high incarceration rates threaten the social fabric of black communities).

86. Kennedy suggests that such a law should be struck down only if it has a "discriminatory purpose," but he would define this phrase more broadly than the Supreme Court has. Kennedy, supra 
How, then, do the federal crack sentences look from the standpoint of mainstream, lowest-common-denominator process theory? They look pretty troubling. The idea behind process theory is that majorities generally can and should be trusted to pass fair laws, or laws that are fair enough, ${ }^{87}$ but that the grounds for trust begin to evaporate in certain circumstances, including when the majority enacts laws that impose a disproportionate share of their burdens on members of a "discrete and insular minority." The problem is especially acute when a law imposes virtually all of its burdens on such a minority. When faced with such a law, courts need to worry that the majority may not have treated members of the minority with equal concern and respect, and that if an appreciable share of the law's burdens fell on members of the majority, the law would never have been enacted or would subsequently have been amended or repealed. In Ely's words, "[t] he function of the Equal Protection Clause . . . is largely to protect against substantive outrages by requiring that those who would harm others must at the same time harm themselves-or at least widespread elements of the constituency on which they depend for reelection." 88

It is hard to find contemporary laws that fail this prophylactic requirement more blatantly than the federal crack penalties. Those penalties do not simply impose a disproportionate share of their burdens on members of a minoritythey impose virtually all of their burdens on them. And blacks are not just any minority-they are the paradigmatic "discrete and insular minority," the minority whose oppression gave rise to equal protection law in the first place. Nor, of course, are long mandatory prison sentences just any burden.

Process theory thus suggests that courts would do well to worry, and to worry hard, about whether the crack sentences might be less severe today if they applied to appreciable numbers of white defendants. ${ }^{89}$ As we have seen,

note 73 , at $1275 \mathrm{n} .85$; see also Kennedy, supra note 71, at 1419-20, 1424 (criticizing "discriminatory purpose" test).

87. Disagreement with this assumption, of course, has been the starting point for some of the most provocative critiques of traditional equal protection theory. See, e.g., Ackerman, supra note 78, at 73137; Richard Davies Parker, The Past of Constitutional Theory-And Its Future, 42 Oно St. L.J. 223 (1981).

88. ELY, supra note 75 , at 170 . Ely notes, for example, that the sterilization law struck down in Skinner v. Oklahoma, 316 U.S. 535 (1942), "involved a discrimination in favor of a class of criminals with whom the legislators could identify and against one with whose members they could not." Id. at 246 n.38. For similar readings of Skinner, see Kenneth L. Karst, Invidious Discrimination: Justice Douglas and the Return of the "Natural-Law-Due-Process Formula," 16 UCLA L. REv. 716, 734-35 (1969); J. Skelly Wright, The Role of the Supreme Court in a Democratic Society-Judicial Activism or Restraint?, 54 CorNell L. Rev. 1, 23, n.111 (1968). Cf., e.g., Personnel Adm'r v. Feeney, 442 U.S. 256,281 (1979) (Stevens, J., concurring) (reasoning that "the number of males disadvantaged by Massachusetts' veterans' preference $(1,867,000)$ is sufficiently large-and sufficiently close to the number of females $(2,954,000)$ - to refute the claim that the rule was intended to benefit males as a class over females as a class'); Railway Express Agency v. New York, 336 U.S. 106, 113 (1949) (Jackson, J., concurring) (arguing that "[c]ourts can take no better measure to assure that laws will be just than to require that laws be equal in operation").

Equal protection, under this view, resembles what John Rawls has called "perfect procedural justice." John RAwLs, A THEORY OF JUSTICE 85 (1971).

89. Actually, as written the crack penalties do apply to an appreciable number of white defendants, even if the vast majority of crack traffickers are in fact black, because the crack penalties apply literally to a large fraction of defendants arrested for dealing in powder cocaine. The Anti-Drug Abuse Act of 1986 imposes mandatory minimum sentences of five or 10 years, respectively, on anyone traf- 
neither the legislative history of the Anti-Drug Abuse Act of 1986, nor the earlier record of American narcotics laws, does much to lessen that worry. And that is why it matters that the crack penalties were set arbitrarily-not because arbitrariness is in and of itself such a bad thing, but because the lack of a principled basis for the quantity thresholds set by Congress makes it particularly difficult to dispel the suspicion that crack defendants would be receiving more lenient sentences if more than a handful of them were white. Caprice is no sin, but it does tend to accommodate sins.

Indeed, one of the strongest arguments raised against the broad sentencing discretion entrusted until recently to federal judges was the danger that sentences set arbitrarily would be influenced by race. 90 Mandatory minimum sentences, together with the Sentencing Guidelines, promised to curb that danger. ${ }^{91}$ The lesson of process theory, however, is that the danger simply resurfaces on a larger scale when it is Congress that sets the penalties, arbitrarily and without guidance, for offenses that it correctly anticipates will be charged almost exclusively against black defendants. ${ }^{92}$

Not all dangers can be avoided, and some are worse than others. That the federal crack sentences are troubling under even a lowest-common-denominator view of equal protection does not necessarily mean that they should be found unconstitutional. What it does suggest is that we should want our law at least to take seriously the indications that the sentences may well be, in some important and intolerable ways, determined by the race of those receiving them. That has not happened, and it is worth asking why.

ficking in more than five or 50 grams of a mixture or substance containing a detectable quantity of cocaine base. 21 U.S.C. $\S 841$ (b)(1)(A)(iii), (B)(iii) (1988 \& Supp. V 1993). "[D]etectable quantities of cocaine base frequently are found in large quantities of cocaine hydrochloride caused by laboratory errors in converting the alkaloid into cocaine hydrochloride." U.S. DEPARTMENT OF JUSTICE, HANDBOOK ON THE ANTT-Drug ABuSE ACT OF 1986, at 16 (1987). Reasoning that Congress did not intend the crack penalties to be applied to traffickers in powder cocaine, however, the Department of Justice concluded soon after the statute's passage that "the lesser quantities applicable to 'cocaine base' [should] be used only in cases where the mixture or substance consists primarily of cocaine base (e.g., 'crack' or cocaine paste)." Id. at 17.

90. See, e.g., Placido G. Gomez, The Dilemma of Difference: Race as a Sentencing Factor, 24 Golden Gate U. L. Rev. 357, 363-64 (1994); Developments in the Law-Race and the Criminal Process, 101 HaRv. L. Rev. 1472, 1626-41 (1988).

91. The shift away from discretionary sentencing by the Sentencing Reform Act of 1984 is generally attributed to "a combined attack by conservatives on judges perceived as lenient and by liberals on racially inequitable sentences." Don J. DeBenedictis, How Long is Too Long?, A.B.A.J., Oct. 1993, at 74; cf. Coramae RICHEY ManN, UneQual Justice: A Question of Color 200 (1993) (noting that "[t]he left thought that determinate sentences would reduce racial disparity and discrimination by reducing individual discretion"); Gomez, supra note 90, at 358-59 (asserting that "[a]mong the factors sparking [sentencing] reform was widespread belief that the sentencing decision was tarnished by racial discrimination").

92. Ironically, racial disparities in federal drug sentences appear to have worsened since 1984, in significant part due to the differential treatment of crack and powder cocaine. See Barbara S. Meierhoefer, The Role of Offense and Offender Characteristics in Federal Sentencing, 66 S. CAL. L. Rev. 367, 388-92 (1992); William W. Schwarzer, Sentencing Guidelines and Mandatory Minimums: Mixing Apples and Oranges, 66 S. CAL. L. REv. 405, 407-09 (1992). One statistical study concluded that the main reason that sentences for black defendants were longer than those for white defendants from January 1989 to June 1990 was that $83 \%$ of all federal offenders convicted of trafficking in crack cocaine were black, and the average sentence imposed for crack trafficking was twice as long as for trafficking in powder cocaine. MCDONALD \& CarLSON, supra note 5, at 1. 


\section{Doctrinal Acutty Assessed}

\section{A. What the Law Sees}

Black defendants have mounted equal protection challenges to the federal crack sentences in each of the regional federal courts of appeals. The precise forms of the challenges have varied. Some defendants have argued that Congress acted unconstitutionally in 1986, some have attacked the Sentencing Commission's extension of the 100:1 ratio adopted by Congress, and some have challenged Congress' and the Commission's failure to amend the ratio when presented with evidence of its overwhelmingly disproportionate impact on black defendants. The results, however, have been remarkably consistent: the defendants always have lost, and the opinions generally have been both unanimous and short. ${ }^{93}$

The reason for this uniform outcome lies less in any lack of sensitivity on the part of circuit judges than in the nature of the rules the Supreme Court has developed for evaluating equal protection challenges. As the courts of appeals have recognized, those rules can be applied rather mechanically to the federal crack sentences, and all but require affirmance.

The rules begin by directing courts to subject the sentences to "rationalbasis" scrutiny. This undemanding form of review is applied because the federal narcotics statute does not discriminate expressly on the basis of race, and cannot be shown to have been motivated in whole or in part by what the Supreme Court has termed a "discriminatory purpose." 94 The Court has defined "discriminatory purpose" to mean, in race cases, out-and-out racial animus - an affirmative desire to hurt blacks. ${ }^{95}$ A facially neutral statute thus qualifies for heightened scrutiny only if it was "enacted or maintained . . . because of an anticipated racially discriminatory effect."

In light of some of the rhetoric surrounding passage of the 1986 statute"big-shouldered Trinidadian," "bands of young black men" peddling crack near

93. See, e.g., United States v. Clary, 34 F.3d 709 (8th Cir. 1994); United States v. Singleterry, 29 F.3d 733 (1st Cir. 1994); United States v. Byse, 28 F.3d 1165 (11 th Cir. 1994); United States v. Thompson, 27 F.3d 671, 678-79 (D.C. Cir. 1994); United States v. Coleman, 24 F.3d 37 (9th Cir. 1994); United States v. Stevens, 19 F.3d 93, 96-97 (2d Cir. 1994); United States v. Bynum, 3 F.3d 769 (4th Cir. 1993); United States v. Chandler, 996 F.2d 917, $918-19$ (7th Cir. 1993); United States v. Reece, 994 F.2d 277 (6th Cir. 1993); United States v. Easter, 981 F.2d 1549, 1558-59 (10th Cir. 1992); United States v. Frazier, 981 F.2d 92, 95 (3d Cir. 1992); United States v. Galloway, 951 F.2d 64 (5th Cir. 1992).

94. Arlington Heights v. Metropolitan Housing Dev. Corp., 429 U.S. 252, 265, 266 (1977); Washington v. Davis, 426 U.S. 229, 239 (1976).

Although current doctrine also applies heightened scrutiny to statutes that burden fundamental rights, the Supreme Court has limited this category to rights "explicitly or implicitly guaranteed by the Constitution." San Antonio Indep. Sch. Dist. v. Rodriguez, 411 U.S. 1, 33-34 (1973). These rights, the Court has held, do not include a convicted defendant's interest in avoiding execution, let alone his or her interest in avoiding lengthy incarceration. See Chapman v. United States, 111 S. Ct. 1919, 1927 (1991); McCleskey v. Kemp, 481 U.S. 279 (1987).

95. See McCleskey, 481 U.S. at 298; Personnel Adm'r v. Feeney, 442 U.S. 256, 279 (1979).

96. McCleskey, 481 U.S. at 298. The "because of" test originated in Feeney: "Discriminatory purpose,' however, implies more than intent as volition or intent as awareness of consequences. . . It implies that the decisionmaker ... selected or reaffirmed a particular course of action at least in part 'because of,' not merely 'in spite of,' its adverse effects upon an identifiable group." 442 U.S. at 279. 
"unsuspecting white retirees"97_it is hardly idle to suggest that the harshness of the crack provisions may in fact reflect some degree of active antipathy toward blacks. But it is difficult if not impossible to prove, in part because hardly anyone admits to racism anymore, and in part because crack posed real dangers as well as symbolic ones, and much of what motivated Congress in 1986 appears to have been a well-founded fear of the drug's actual effects, on blacks as well as on whites. ${ }^{98}$ Applying the equal protection rules developed by the Supreme Court, the federal appeals courts therefore have subjected the federal crack sentences only to rational-basis scrutiny. 99

That scrutiny, the Supreme Court has further explained, consists of asking only whether Congress was pursuing a legitimate goal, and whether the classification drawn by Congress is rationally related to that goal. ${ }^{100}$ The federal crack sentences pass these tests easily. The overriding purpose of the crack penalties is the plainly legitimate goal of reducing drug abuse. Just as plainly, the distinction Congress drew, and has maintained, between crack and powder cocaine is rationally related to that goal, because crack is more dangerous than powder cocaine. The federal courts of appeals thus have had no trouble concluding that the crack sentences pass rational-basis scrutiny and hence comply with equal protection. ${ }^{101}$

Alternative challenges to the crack sentences have fared no better. Without exception, the courts of appeals have rejected arguments that the sentences constitute cruel and unusual punishment in violation of the Eighth Amendment, ${ }^{102}$

97. See notes 49-51 supra and accompanying text.

98. See, e.g., United States v. Clary, 34 F.3d 709, 713 (8th Cir. 1994) (concluding that "[i]t is too long a leap from newspaper and magazine articles to an inference that Congress enacted the crack statute because of its adverse effect on African American males"); United States v. Walls, 841 F. Supp. 24, 3132 (D.D.C. 1994) (noting "the racist origins of the Harrison Act [and] the racist implications arising from the public clamor in 1986 about crack in the inner city," but concluding that "[t]he racial implications of the legislative history of the 1986 Act and its 1914 predecessor are too sparse, too tangential, or too remote in time to support a finding that a majority in Congress in 1986 intended the crack penalties to discriminate against blacks"); United States v. McMurray, 833 F. Supp. 1454, 1464, 1467 (D. Neb. 1993), aff' $d, 34$ F.3d 1405 (8th Cir. 1994) (concluding that "the legislative history of congressional efforts to stop the flow of 'crack' strongly suggests that Congress was aware that African Americans would be 'disproportionately' prosecuted for 'crack' violations," but that "there is no evidence of racial animus towards blacks in the adoption of the 'crack' penalties by Congress or the Sentencing Commission").

99. See, e.g., Bymum, 3 F.3d at 775 (finding no equal protection violation because defendant could not show that the 100:1 ratio had been "enacted for the discriminatory purpose of punishing blacks more than whites for similar culpable conduct"); accord, e.g., Clary, 34 F.3d at 712; Singleterry, 29 F.3d at 740-41; Byse, 28 F.31 at 1170; Thompson, 27 F.3d at 678; Stevens, 19 F.3d at 96; Easter, 981 F.2d at 1559; Frazier, 981 F.2d at 95; King, 972 F.2d at 1260; Galloway, 951 F.2d at 66.

100. See, e.g., Schweiker v. Wilson, 450 U.S. 221,230 (1981). Actually, the test is even weaker: The legitimate goal furthered by the classification need not have been one Congress actually considered. See United States R.R. Retirement Bd. v. Fritz, 449 U.S. 166, 179 (1980).

101. See, e.g., Clary, 34 F.3d at 712; Singlterry, 29 F.3d at 740-41; Stevens, 19 F.3d at 97; King, 972 F.2d at 1260; United States v. Harding, 971 F.2d 410, $412-14$ (9th Cir. 1992); cf. Leitman, supra note 85 , at 219,242 (arguing that in practice there are at least two different versions of the rational-basis test, but that the federal crack penalties satisfy even the more demanding version).

102. See, e.g., Frazier, 981 F.2d at 95-96; United States v. Avant, 907 F.2d 623, 627 (6th Cir. 1990). But see Walls, 841 F. Supp. at 32 (concluding that applying crack penalties to "bit players," who converted powder cocaine into crack for the profit of other defendants and at the instigation of undercover officers, would constitute cruel and unusual punishment). 
and that the racially lopsided impact of the crack penalties warrants a downward departure from the sentencing range prescribed by the Sentencing Guidelines. ${ }^{103}$

The crack cases make instructive reading for anyone skeptical about the practical significance of doctrinal rules. The virtually unanimous, typically summary rejection of equal protection challenges to federal crack sentences does not reflect widespread judicial approval of the sentences-far from it. Even while affirming the sentences, federal judges repeatedly have condemned them, in unusually strong terms, as excessive and unjust. ${ }^{104}$ The results in these cases arise not from judicial predilection but from legal doctrine.

The force of that doctrine is perhaps best illustrated by the extent to which courts have had to strain to avoid its apparent implications. In 1991, for example, Minnesota's highest court invalidated a state penalty prescribed for possession of three grams of crack or ten grams of powder cocaine-a 3:1 ratio far milder than the federal ratio of 100:1.105 To strike down the law, the court found it necessary to conclude that the equal protection clause of Minnesota's state constitution imposed a "stricter standard of rational basis review" than its federal analogue, ${ }^{106}$ and that, for reasons unexplained, the differential treatment of crack and powder cocaine could not be rationally justified by "effects resulting from different methods of ingestion, rather than on an inherent difference between the forms of the drug." 107 Similarly, in the sole federal decision strik-

103. See, e.g., United States v. Maxwell, 25 F.3d 1389, 1400-01 (8th Cir. 1994). But cf. United States v. Lattimore, 974 F.2d 971, 977 (8th Cir. 1992) (dissenting opinion) (arguing that "because the Sentencing Commission skewed the Guidelines by overlooking Congress' minimum sentence and further because the Sentencing Commission never considered the racial disparity resulting from crack Guidelines, the district court possessed the authority to depart downward from the Guidelines").

104. See, e.g., United States v. Moore, No. 94-1330, 1995 U.S. App. LEXIS 9595, *16, *32 (2d Cir. Apr. 25, 1995) (rejecting arguments that federal crack penalties violate equal protection, but characterizing those arguments as "compelling' and concluding that they "raise troublesome questions about the fairness of the crack cocaine sentencing policy"); Singleterry, 29 F.3d at 741 (concluding that "[a]lthough Singleterry has not established a constitutional violation, he has raised important questions about the efficacy and fairness of our current sentencing policies for offenses involving cocaine substances"); United States v. Willis, 967 F.2d 1220, 1226 (8th Cir. 1992) (concurring opinion) (affirming 15-year crack sentence but suggesting that Congress had no "sound basis to make the harsh distinction between powder and crack cocaine," and quoting with approval district judge's description of the sentence as a "tragedy"); United States v. Conard, No. 92-00137-03-CR-W-6, 1994 U.S. Dist. LEXIS $3259, * 3$ (W.D. Mo. Mar. 16, 1994) (upholding the crack sentencing provisions of the 1986 statute and the Sentencing Guidelines, but observing that "[f]ederal judges appear to be uniformly appalled by the severe crack cocaine punishments, particularly as compared with the more moderate punishments mandated for transactions in ordinary, powdered cocaine"); United States v. Patillo, 817 F. Supp. 839, 84344 \& n.6 (C.D. Cal. 1993) (imposing 10-year mandatory minimum sentence for crack trafficking on black defendant, but characterizing sentence as "barbaric," and criticizing 100:1 ratio as "arbitrary at best" and responsible for instituting "racial disparity in sentencing").

Testifying before Congress in March 1994, Justice Kennedy expressed his agreement "with most judges in the Federal system that mandatory minimums are an imprudent, unwise and often unjust mechanism for sentencing," and he singled out the crack sentences for special criticism: "I simply do not see how Congress can be satisfied with the results of mandatory minimums for possession of crack cocaine." Mandatory Sentencing is Criticized by Justice, N.Y. TnMes, Mar. 10, 1994, at A22 (quoting testimony of Justice Kennedy).

105. State v. Russell, 477 N.W.2d 886 (Minn. 1991).

106. Id. at 889 .

107. Id. at 890 . 
ing down the crack sentences on equal protection grounds, ${ }^{108}$ District Judge Clyde Cahill relied not only on a debatable finding that the "[o]bjective evidence supports the belief that racial animus was a motivating factor in enacting the crack statute," 109 but also on a demonstrably incorrect assertion that "there is no reliable medical evidence that crack cocaine is more addictive than powder cocaine."110 Judge Cahill's decision was later reversed on appeal.

Both Judge Cahill and the Minnesota court recognized that their decisions ran counter to the Supreme Court's equal protection jurisprudence, and both strained mightily, albeit in the end unconvincingly, to avoid the implications of that jurisprudence. They did so, it is worth noting, because they found current doctrine blind to critical dimensions of racial unfairness. Thus, the Minnesota court proclaimed, almost defiantly, that "[t]here comes a time when we cannot and must not close our eyes when presented with evidence that certain laws, regardless of the purpose for which they were enacted, discriminate unfairly on the basis of race."111 Judge Cahill struck a similar note when he explained that the federal crack sentences "created a situation that reeks with inhumanity and injustice" and that "emboldened [him] to express a viewpoint designed to eliminate the disproportionate punishment for crack."112 While acknowledging that his decision might not be "in keeping with the majority of opinions currently controlling the law," he protested that "[t]ruth must be recognized and respected." 113

\section{B. What the Law Misses}

The force of Judge Cahill's protest was unfortunately undercut by his own failure to recognize and respect the genuine and important differences between crack and powder cocaine. He shared this failure with the Supreme Court of Minnesota. But while both courts' reasoning has understandably received serious criticism, ${ }^{114}$ it is harder to dismiss the concern running just below the surface of the two decisions - a concern that current equal protection law finds far too much invisible. ${ }^{115}$

108. United States v. Clary, 846 F. Supp. 768 (E.D. Mo.), rev'd, 34 F.3d 709 (8th Cir. 1994).

109. Id. at 787 .

110. Id. at 792. Judge Cahill also found that the racially disproportionate impact of the crack sentences had been exacerbated by discriminatory enforcement practices. See id. at 787-91.

111. State v. Russell, 477 N.W.2d 886, 888 n.2 (Minn. 1991).

112. Clary, 846 F. Supp. at $772-73$.

113. Id. at 794.

114. See United States v. Clary, 34 F.3d 709 (8th Cir. 1994), rev'g 846 F. Supp. 768 (E.D. Mo.); Stith, supra note 83, at 153 (criticizing Minnesota decision); Kennedy, supra note 73, at 1261-70 (same); Rakoff, supra note 2, at 96-97 (same). For a more sympathetic discussion of the Minnesota Supreme Court's decision in Russell, see Lowney, supra note 20, at 161-67.

115. Indeed, following the Minnesota Supreme Court's decision in Russell, several judges on the Eighth Circuit expressed misgivings about that court's earlier rejection of equal protection challenges to the federal crack penalties. See United States v. Willis, 967 F.2d 1220, 1226 (8th Cir. 1992) (Heaney, J., concurring) ("I concur in the court's opinion, but only because I am bound by our prior decisions that hold there is no merit in Willis' equal protection argument."); United States v. Simmons, 964 F.2d 763, 767 (8th Cir. 1992) ("Were we writing from a clean slate, however, we might accept as valid appellants' contentions relating to the disproportionate penalty."). 
That concern is well founded. The analysis of the federal crack sentences under current equal protection law is indeed disquieting. This is not so much because the analysis leads to affirmance of the sentences, although I will argue later that a more sensible law of equal protection might well require their invalidation. Rather, what is most troubling about the analysis is that it entirely ignores three important aspects of the problem. The first of these is the persistent danger of forms of racism more stubbornly intractable than overt racial animus; the second is the extent of the differential treatment of crack and powder cocaine; and the third is the special nature of the burden imposed by the challenged statute.

\section{The danger of unconscious racism.}

Writing nearly twenty years ago, Paul Brest pointed out that laws not motivated by a conscious, affirmative desire to hurt blacks may still be the product of racism, and may still be objectionable under a narrow, process-theory view of equal protection, if they result from or are retained because of "racially selective sympathy and indifference"-an "unconscious failure to extend to a minority the same recognition of humanity, and hence the same sympathy and care, given as a matter of course to one's own group."116 Such laws, Brest argued, "violat[e] the cardinal rule of fairness- the Golden Rule."117 (They also, it should be clear, fail to satisfy Ely's test for avoiding "substantive outrages"- the requirement "that those who would harm others must at the same time harm themselves-or at least widespread elements of the constituency on which they depend for reelection."118) Accordingly, Brest concluded that equal protection is violated whenever members of a minority group are disadvantaged by government action that is "race-dependent" in the sense that it "would have been different but for the race of those benefitted or disadvantaged."119

Building on Brest's thesis, Charles Lawrence and others have argued that the Supreme Court's "discriminatory purpose" test blinds the law to a significant set of concerns that a process-theory view of equal protection demands be treated seriously. 120 Among the most important "process distortions" caused by prejudice, Lawrence has argued, are those caused by unconscious racism ${ }^{121}$ — what Brest called "racially selective sympathy and indifference."122 Current doctrine ignores those distortions "by only suspecting laws that classify by race on their face or are the result of overtly self-conscious racial motiva-

116. Brest, supra note 75 , at $7-8$.

117. Id. at 8.

118. ELY, supra note 75 , at 170 .

119. Brest, supra note 75, at 6; see also, e.g., David A. Strauss, Discriminatory Intent and the Taming of Brown, 56 U. CHI. L. REV. 935, 957 (1989) (arguing that "the only plausible definition of discriminatory intent" includes any decision that would have been different if "the adverse effects of the challenged government decision fell on whites instead of blacks, or on men instead of women").

120. See Charles R. Lawrence III, The Id, the Ego, and Equal Protection: Reckoning with Unconscious Racism, 39 STAN. L. REv. 317 (1987); see also Sheri Lynn Johnson, Unconscious Racism and the Criminal Law, 73 CORNELL L. Rev. 1016 (1988); Kennedy, supra note 71; Rakoff, supra note 2; Eric Schnapper, Two Categories of Discriminatory Intent, 17 HARv. C.R.-C.L. L. REv. 31 (1982).

121. Lawrence, supra note 120 , at 347.

122. See note 116 supra. 
tion."123 This focus not only forces process theory to stop an "important step short of locating and eliminating the defect it has identified,"124 but, as Randall Kennedy has observed, it makes equal protection law increasingly obsolete: "By conditioning the availability of a remedy under the fourteenth amendment on proof that a decisionmaker purposefully set out to harm a person or group because of race," the Supreme Court "display[s] minds trapped by old conquests - the battles against de jure segregation and overt, intentional discrimination in the administration of statutes making no mention of race."125

The federal crack penalties provide a paradigmatic case of unconscious racism. While these penalties may reflect some degree of affirmative antipathy toward blacks, the evidence of that is at best suggestive and anecdotal. What the legislative history of the Anti-Drug Abuse Act and its predecessors provide a good deal more reason to suspect is that, regardless of the objectives Congress was pursuing, it would have shown more restraint in fashioning the crack penalties, or more interest in amending them in ensuing years, ${ }^{126}$ if the penalties did not apply almost exclusively to blacks. In the words of one defense attorney, "Maybe I'm cynical, but I think that if you saw a lot of young white males getting five- and 10-year minimums for dealing powder cocaine, you'd have a lot more reaction."127

This is a kind of danger to which our law is completely blind. Reversing Judge Cahill's decision for example, the Eighth Circuit reasoned that the crack penalties were constitutional because "the members of Congress did not have racial animus, but rather 'racial consciousness,' an awareness that the 'problem in the inner cities ... was about to explode into the white parts of the country." "128 Under current equal protection doctrine, that is where the analysis of legislative motive ends.

123. Lawrence, supra note 120 , at 349.

124. Id.; see also, e.g., Strauss, supra note 119, at 960 (noting that "if one is concerned about impermissible partiality, there is no reason to confine the inquiry to conscious partiality").

125. Kennedy, supra note 71, at 1419; see also Karst, supra note 72, at 51 (arguing that "[ $[\mathrm{t}] \mathrm{he}$ main difference between [modern racism and Jim Crow] is that today's racism inflicts a greater proportion of its harms unthinkingly"); $c f$. DeRrICK BeLL, AND We ARE Not SAVEd 162-77 (1987) (debating the causes and meaning of "the declining importance of the equal-protection clause").

126. Cf. Gumelines Manual, supra note 8, Appendix C, amend. 488, at 324-25 (amending guidelines for LSD sentences to eliminate dependence on weight of carrier medium, in part to redress "disproportionate" severity of LSD penalties compared to penalties for offenses involving other drugs). More than $95 \%$ of federal LSD defendants are white. See 1993 AnNual REPORT, supra note 5, at 152. McLane).

127. Jim Newton, supra note 23, at A20 (quoting Deputy Federal Public Defender David S.

Judge Cahill reached a similar conclusion:

[U]nconscious racism is patently evident in the crack cocaine statutes. Had the same type of law been applied to powder cocaine, it would have sentenced droves of young whites to prison for extended terms. Before the enactment of such a law, it would have been much more carefully and deliberately considered.

United States v. Clary, 846 F. Supp. 768, 779 (E.D. Mo.), rev'd, 34 F.3d 709 (8th Cir. 1994).

128. United States v. Clary, 34 F.3d. 709, 714 (8th Cir. 1994) (quoting testimony by Eric Sterling) (omission in original). 


\section{The extent of the differential treatment.}

Because of the blindness equal protection doctrine shows to the danger of unconscious racism, the federal crack sentences have been assessed only for "rational basis." The nature of that assessment, in turn, has blinded our law to a second troubling feature of the sentences-the severity of the difference between the penalties for crack and those for cocaine powder. The rational-basis test asks only whether the line Congress has drawn is rationally related to a legitimate governmental interest; the test entirely ignores how and to what extent Congress has made the line count. Current doctrine thus directs courts to inquire whether it is reasonable for Congress to distinguish between crack and powder cocaine, but not whether it is reasonable to distinguish between them by treating an ounce of one the same as 100 ounces of the other.

Unfortunately, it is precisely here, in the extent of the differential treatment, that one would most expect unconscious racism to manifest itself. The problem of "racially selective sympathy and indifference" becomes most acute not when Congress divides people into classes, but when it determines what treatment people in each class should receive. Far from operating independently, then, the blindness of current doctrine to unconscious racism and to the extent of differential treatment reinforce each other. Together they render virtually invisible to equal protection analysis much of what is most troubling about the federal crack sentences.

\section{The nature of the burden imposed.}

Nor is that the worst of it. Current doctrine is blind in a third and more fundamental way.

To a non-lawyer, the most striking thing about the decisions upholding the federal crack sentences might be that the doctrinal rules applied there were developed for the most part in business regulation cases that lacked any racial issues. Yet no court has stopped to ask whether those rules should apply in the very different context of criminal sentencing laws that impose a dramatically disproportionate burden on blacks. That is because, at least since the Supreme Court's decision nearly a quarter-century ago in Dandridge v. Williams, ${ }^{129}$ the first and usually unstated assumption of equal protection law has been that the rules should be the same across the board, regardless of the factual context giving rise to a claim of unequal treatment.

Dandridge upheld a state law placing a per family ceiling on welfare benefits regardless of family size or actual need. The Court found no violation of equal protection because the law did not discriminate on its face, and because it appeared rationally related to legitimate state interests in "encouraging employment" and "maintain[ing] some semblance of an equitable balance between families on welfare and those supported by an employed breadwinner"-despite the Court's recognition that some welfare families might not have a poten-

129. 397 U.S. 471 (1970). 
tial "breadwinner."130 Justice Marshall protested in dissent that the rationalbasis test had been developed in business cases, in response to "a healthy revulsion from the Court's earlier excesses in using the Constitution to protect interests that have more than enough power to protect themselves in the legislative halls."131 Without straying from a conventional, process-theory view of equal protection, Marshall noted the absurdity of treating "the literally vital interests of a powerless minority-poor families without breadwinners"-the same as the business interests of "a gas company or an optical dispenser."132 The majority, for its part, acknowledged "the dramatically real factual difference" between welfare rules and business regulations, but found "no basis for applying a different constitutional standard."133

By its terms, Dandridge extended rational-basis review only to "state regulation in the social and economic field,"134 and the Court was careful to suggest that heightened scrutiny might be warranted if the statute before it were "infected with a racially discriminatory purpose or effect."135 But these qualifications were soon forgotten as the Court took firmly to heart the central idea of Dandridge: that the rules of equal protection should be globally applicable, notwithstanding "dramatically real factual differences" in the cases giving rise to complaints of inequity. In time, even many of the Court's critics grew to accept its assumption that, for the most part, all equal protection cases-regardless of whether they involved prison sentences or eyeglass regulation, and regardless of whether they arose under the Equal Protection Clause of the Fourteenth Amendment or the Due Process Clause of the Fifth Amendment ${ }^{136}$ should be addressed by a single, unified body of doctrine. ${ }^{137}$

130. Id. at 486 .

131. Id. at 520 (Marshall, J., dissenting).

132. Id. at 520, 529 (Marshall, J., dissenting) (distinguishing Lindsley v. Natural Carbonic Gas Co., 220 U.S. 61 (1911) and Williamson v. Lee Optical Co., 348 U.S. 483 (1955)).

133. Id. at 485 .

134. Id. at 484 .

135. Id. at $485 \mathrm{n} .17$ (emphasis added).

136. With remarkably little explanation, the Supreme Court has treated equal protection claims arising under the Due Process Clause of the Fifth Amendment, which restricts the federal government, virtually the same as those arising under the Equal Protection Clause of the Fourteenth Amendment, which applies only to the states. See Adarand Constructors, Inc. v. Pena, 63 U.S.L.W. 4523, 4527-30 (June 12, 1995); San Francisco Arts \& Athletics v. United States Olympic Comm., 483 U.S. 522, 542 n.21 (1987); Weinberger v. Wiesenfeld, 420 U.S. 636, 638 n.2 (1975); Kenneth L. Karst, The Fifth Amendment's Guarantee of Equal Protection, 55 N.C. L. REv. 541 (1977). The sole exception to this uniform treatment is Hampton v. Mow Sun Wong, 426 U.S. 88 (1976), in which the Supreme Court suggested in dicta that "overriding national interests" might permit the federal government to discriminate against documented aliens in a manner forbidden to the states. Id. at 100 .

137. In a long series of dissents, Justice Marshall continued to protest "the Court's rigidified approach to equal protection analysis." San Antonio Indep. Sch. Dist. v. Rodriguez, 411 U.S. 1, 98 (1973) (Marshall, J., dissenting). By treating factual context as irrelevant, Marshall charged, the Court's equal protection jurisprudence called upon judges to "ignore what everyone knows." Richardson v. Belcher, 404 U.S. 78, 90 (1971) (Marshall, J., dissenting). Rather than propose a disaggregation of equal protection doctrine, however, Marshall called for a single, sliding-scale standard of review, varying in a largely undefined way according to "the character of the classification in question, the relative importance to individuals in the class discriminated against of the governmental benefits that they do not receive, and the asserted state interests in support of the classification." Dandridge v. Williams, 397 U.S. 471, 521 (1970) (Marshall, J., dissenting); see also, e.g., Lyng v. Castillo, 477 U.S. 635, 643-44 (1986) (Marshall, J., dissenting); Harris v. McRae, 448 U.S. 297, 341 (1980) (Marshall, J., dissenting); 
There have been some notable exceptions to this universalist approach. In addition to the heightened scrutiny applied to purposeful discrimination and the rationality review applied to most other laws, the Supreme Court has crafted a form of "intermediate scrutiny" for reviewing discrimination on the basis of gender. ${ }^{138}$ More to the point, the Court has developed special equal protection rules for cases involving school desegregation, ${ }^{139}$ voting rights, ${ }^{140}$ and jury selection. ${ }^{141}$ For cases in each of these categories, the Court has shifted the burden to the government to defend certain conduct giving rise to racially disproportionate results. ${ }^{142}$ But the Court generally has been hostile to the expansion of these categories or to the creation of any new ones. ${ }^{143}$ Thus, even a defendant sentenced to death in a state shown statistically to discriminate on the basis of race can prevail under the equal protection clause only by "prov[ing] that the decisionmakers in his case acted with discriminatory purpose."144

As a result, we now have a law of equal protection that directs courts reviewing the federal crack sentences to ignore the problem of unconscious racism, to ignore the severity of the difference in treatment between defendants caught with crack and those caught with cocaine powder, and to ignore the fact that the statute at issue parcels out not business costs but criminal sentences, and criminal sentences imposed almost exclusively on black defendants. Any body of doctrine, of course, will treat some facts as relatively insignificant; "every way of seeing is also a way of not seeing." 145 But some things are more important to see than others. Our law blinds courts to the very features of the federal crack sentences that are the most troubling and that raise the most serious concerns for the traditional goals of equal protection jurisprudence. We should not find this acceptable.

Beal v. Doe, 432 U.S. 438, 457 (1977) (Marshall, J., dissenting); Massachusetts Bd. of Retirement v. Murgia, 427 U.S. 307, 318 (1975) (Marshall, J., dissenting). Justice Stevens has advocated a similarly ad hoc approach. See, e.g., City of Cleburne v. Cleburne Living Center, Inc., 473 U.S. 432, 452 (1985) (Stevens, J., concurring); Craig v. Boren, 429 U.S. 190, 212 (1976) (Stevens, J., concurring).

Addressing equal protection challenges on an ad hoc basis would make a good deal more sense than reviewing the federal crack penalties "under the same minimal standards of rationality [applied] to statutes regulating who can sell eyeglasses or who can own pharmacies." Marshall v. United States, 414 U.S. 417, 433 (1973) (Marshall, J., dissenting). But by abandoning doctrinal structure altogether, the approach championed by Justices Marshall and Stevens would expose the Court to charges of unguided subjectivism, and, like the Court's current approach, would largely forfeit the dialectic benefits of doctrinal development. See Part III infra.

138. See, e.g., Clark v. Jeter, 486 U.S. 456,461 (1988) (gender classifications "must be substantially related to an important government objective"); Craig v. Boren, 429 U.S. 190, 197 (1976) (same).

139. See, e.g., Swann v. Charlotte-Mecklenberg Bd. of Educ., 402 U.S. I (1971).

140. See, e.g., Harper v. Virginia Bd. of Elections, 383 U.S. 663 (1966).

141. See, e.g., Batson v. Kentucky, 476 U.S. 79 (1986) (peremptory challenges); Castaneda v. Partida, 430 U.S. 482 (1977) (grand jury empanelment).

142. See Ortiz, supra note 78 , at 1119-34.

143. But cf. Julian N. Eule, Judicial Review of Direct Democracy, 99 Y ALE L.J. 1503, 1562-67 (1990) (suggesting that the Supreme Court in Washington v. Seattle Sch. Dist. No. 1, 458 U.S. 457 (1982), may have groped, for good reason, toward a more demanding form of equal protection review for voter initiatives that bypass the normal processes of representative democracy).

144. McCleskey v. Kemp, 481 U.S. 279, 292 (1987) (emphasis in original).

145. Helen Merreli Lynd, ON Shame and the Search for Identity 16 (1958). 


\section{A REMEdy Proposed}

\section{A. The Universalist Approach}

How did equal protection law become so blind, and what are the prospects for improving its vision? Current scholarship, for the most part, offers two answers. The mainstream answer blames a particular doctrinal rule-the requirement of discriminatory purpose-and argues that the rule needs to be thoroughly recrafted across the board or altogether junked. ${ }^{146}$ The more radical answer suggests that our legal system is inherently incapable of moving toward anything even resembling genuine equality, and therefore that the sad state of equal protection law is neither surprising nor, as a practical matter, remediable. ${ }^{147}$

Neither answer is fully satisfactory. For reasons I discuss below, criticisms of the discriminatory purpose requirement, although manifestly well-founded, typically founder in attempting to fashion a workable substitute that is coherent, broadly acceptable, and sufficiently sensitive to contemporary forms of inequality. In particular, some of the substitutes proposed might not do much better than current doctrine in calling the attention of courts to the troubling features of the federal crack sentences. ${ }^{148}$ And while the history of equal protection jurisprudence provides ample grounds for pessimism, neither history nor morality permits us to give up equal protection law for dead. ${ }^{149}$

146. See, e.g., Gayle Binion, "Intent" and Equal Protection: A Reconsideration, 1983 Sur. CT. REv. 397; Theodore Eisenberg, Disproportionate Impact and Illicit Motive: Theories of Constitutional Adjudication, 52 N.Y.U. L. REv. 36 (1977); Johnson, supra note 120; Lawrence, supra note 120, at 317; Rakoff, supra note 2; Pamela S. Karlan, Note, Discriminatory Purpose and Mens Rea: The Tortured Argument of Invidious Intent, 93 Y ALE L.J. 111 (1983).

147. See, e.g., Girardeau A. Spann, Race Against the Court: The Supreme Court and MINORTIIES IN CONTEMPORARY AMERICA 150-71 (1993); Alan D. Freeman, Legitimizing Racial Discrimination Through Antidiscrimination Law: A Critical Review of Supreme Court Doctrine, 62 Mins. L. REv. 1049 (1978); Louis Michael Seidman, Brown and Miranda, 80 CAL. L. REv. 673 (1992).

148. Charles Lawrence, for example, has proposed replacing the discriminatory purpose requirement with a test addressed to the "cultural meaning" of a challenged action. His test "would evaluate governmental conduct to see if it conveys a symbolic message to which the culture attaches racial significance." Lawrence, supra note 120, at 355-56. Similarly, Todd Rakoff has argued that equal protection doctrine should focus on "[t]he objective, or social, meaning of an official action." Rakoff, supra note 2, at 84 . It is far from clear that courts would find the federal crack penalties any more troubling under these tests than under current law. Lawrence himself suggests that laws that disproportionately disadvantage blacks should fail the test only if there is "evidence that a substantial part of the population will interpret the disproportionate results" as testimony to blacks' inherent inferiority. Lawrence, supra note 120 , at 373 . Increases in bus or train fares would pass the test, for example, because "we do not think of fare increases in racial terms." Id. at 365. Rakoff suggests that the constitutionality of heightened penalties for crack trafficking should depend on a whole range of "cultural evidence," including whether crack is "a race-related symbol in the culture," whether the statutory distinction is "legitimately understood in terms of public safety," whether black leaders "welcomed the disparate impact as tending to provide extra protection to their communities," and the entire nature of "the political story . . . beyond the psyches of the specific legislators." Rakoff, supra note 2, at 97-98.

The difficulty of determining the "cultural" or "objective meaning" of the federal crack penalties highlights the troubling ambiguity of the tests proposed by Lawrence and Rakoff. Whose meaning is dispositive, how do we divine it, and what kinds of meanings are forbidden? It is not encouraging that both Lawrence and Rakoff point to Establishment Clause jurisprudence as a model for the kind of inquiry they propose. See Lawrence, supra note 120, at 359; Rakoff, supra note 2, at $90 \&$ n.100.

149. See Crenshaw, supra note 71 , at 1356-69, 1381-87. 
There may be a better answer, one lying somewhere between a quarrel with a particular rule and a wholesale condemnation of our legal system. Perhaps the problem is one of approach: in large part, perhaps, the blindness of equal protection doctrine may be traced to the doctrine's universalist ambitions. The wrong turn, from this perspective, came not in Washington v. Davis, ${ }^{150}$ when the Court adopted a requirement of discriminatory purpose, but earlier, in Dandridge $v$. Williams, ${ }^{151}$ when the Court committed itself to promulgating a single, globally applicable set of equal protection rules. ${ }^{152}$

The universalist approach to equal protection has obvious attractions: "[i]t is always appealing to look for a single test, a Grand Unified Theory that would resolve all the cases that may arise under a particular clause."153 Part of this appeal, no doubt, is aesthetic. Judges and law professors no less than physicists are enticed by the notion of "a final theory, one that would be of unlimited validity and entirely satisfying in its completeness and consistency." 154 In law, moreover, universalism also has significant practical advantages. Compared to a host of narrow rules, a single, unified set of rules can be expected to be easier for the Supreme Court to manage, simpler for lower courts to apply, and more predictable for potential litigants. ${ }^{155}$ Finally, beyond considerations of aesthetics and practicality, a unified set of rules can seem more logically consistentand, as a consequence, less arbitrary-than a hodgepodge of context-specific

150. 426 U.S. 229 (1976).

151. 397 U.S. 471 (1970).

152. David Strauss made a similar suggestion several years ago. "[W]hat makes Washington $v$. Davis problematic," he argued, is "[t]he claim that the discriminatory intent standard is a comprehensive account of discrimination." Strauss, supra note 119, at 953.

153. Board of Educ. of Kiryas Joel Village Sch. Dist. v. Grumet, 114 S. Ct. 2481, 2498-99 (1994) (O'Connor, J., concurring).

154. Steven Wennberg, Dreams of a Finai Theory 6 (1992). Not everyone, of course, shares the same aesthetics. See, e.g., Wallace Stevens, The Poems of Our Climate, in The Palm at the END of the Mind: Selected PoEms ANd a Play 158 (Holly Stevens ed., Alfred A. Knopf 1971) (1967) ("The imperfect is our paradise. / Note that, in this bittemess, delight, / Since the imperfect is so hot in us, / Lies in flawed words and stubborn sounds."). Neither physics nor aesthetics, moreover, may be a particularly good model for law. Cf. Isaiah Berlin, The Decline of Utopian Ideas in the West, in THE Crooked Timber of HumantTy: Chapters In the History of Ideas 48 (Henty Hardy ed., 1990) ("Immanuel Kant, a man very remote from irrationalism, once observed that 'Out of the crooked timber of humanity no straight thing was ever made.' And for that reason no perfect solution is, not merely in practice, but in principle, possible in human affairs, and any determined attempt to produce it is likely to lead to suffering, disillusionment and failure.").

155. Skeptics might question the simplicity and predictability of current equal protection doctrine, but these advantages do appear to be borne out by the litigation over the federal crack penalties. Despite the serious equity concerns those penalties raise, astute litigants should have had little trouble guessing how the courts would rule, the lower courts have in fact had little difficulty deciding how to rule, and the Supreme Court has not had to rule at all. What the crack cases suggest is not that current equal protection law can make no claim to predictability, but that the predictability it can claim is one we should not want-a predictability borne of treating significant categories of racial unfairness as legally uncognizable. 
doctrines. ${ }^{156}$ After all, as Justice Stevens has written, "[ $t$ ]here is only one Equal Protection Clause."157

Notwithstanding these allures, the crack cases suggest that the universalist approach has produced, in practice, a remarkably unsatisfactory law of equal protection. In retrospect, perhaps, this should not have been surprising. Equality is a concept of explosive potential, famously difficult to "cabin."158 The Supreme Court, if for no other reason than who its members tend to be, is an inherently conservative institution, and has long been chary of carrying equality too far. ${ }^{159}$ The universalist approach, by forcing the Court to write rules of global application, has therefore resulted in a kind of dumbing down of equal protection. When faced with a novel equal protection claim, particularly one based to any extent on racially disproportionate impact, the Court has tended to worry about the implications of its decision for the entire range of government action-and then to reject the argument. ${ }^{160}$ It is as though the Court has said to the parties raising these claims, "Before we are willing to consider your argument about what equal protection means here, you must tell us, and convince us, what it means everywhere." Not surprisingly, this challenge proves impossible to meet.

It cannot be met because the essential content of equal protection remains so thoroughly up for grabs. As a society, we are not only far from achieving true equality, but also far from understanding, let alone agreeing about, what

156. See, e.g., Melvin Aron Eisenberg, The Nature of the Common Law 48 (1988) (noting that "[ $t]$ he concept of universality instructs a court not to decide a case on the basis of a rule unless it is ready to apply the rule to all similarly situated disputants"); HARRY H. WELLINGTON, INTERPRETING THE Constitumion: The Supreme Court and the Process of Adudication 81-82 (1990) (arguing that "a commitment to the rule of law . . . require[s] that like cases be treated alike").

157. Craig v. Boren, 429 U.S. 190, 211-12 (1976) (Stevens, J., concurring).

158. Archibald Cox, The Supreme Court, 1965 Term, Foreword: Constitutional Adjudication and the Promotion of Human Rights, 80 HaRv. L. Rev. 91,91 (1966).

159. See, e.g., Trimble v. Gordon, 430 U.S. 762, 777 (1977) (Rehnquist, J., dissenting) (characterizing equal protection law as a judicial "cat-o'-nine-tails"); Railway Express Agency v. New York, 336 U.S. 106, 111 (1949) (Jackson, J., concurring) ("While claims of denial of equal protection are frequently asserted, they are rarely sustained."); Buck v. Bell, 274 U.S. 200, 208 (1927) (Holmes, J.) (disparaging equal protection as "the usual last resort of constitutional arguments").

160. The best known expression of this worry is the parade of horribles in Washington v. Davis:

A rule that a statute designed to serve neutral ends is nevertheless invalid, absent compelling justification, if in practice it benefits or burdens one race more than another would be far reaching and would raise serious questions about, and perhaps invalidate, a whole range of tax, welfare, public service, regulatory, and licensing statutes that may be more burdensome to the poor and to the average black than to the more affluent white.

426 U.S. 229, 248 (1976). For similar sentiments see, e.g., San Antonio Indep. Sch. Dist. v. Rodriguez, 411 U.S. 1, 37 (1973) ("How, for instance, is education to be distinguished from the significant personal interests in the basics of decent food and shelter?"); Palmer v. Thompson, 403 U.S. 217, 228 (1971) (Burger, C.J., concurring) ("To find an equal protection issue in every closing of public swimming pools, tennis courts, or golf courses would distort beyond reason the meaning of that important constitutional guarantee."); $c f$. McCleskey v. Kemp, 481 U.S. 279, 314-18 (1987) (waming that McCleskey's Eighth Amendment claim, "taken to its logical conclusion, throws into serious question the principles that underlie our entire criminal justice system. ... [t] lenge brought by McCleskey.").

As Kenneth Karst has noted, "[t]he specter of the stopping place problem, it would seem, is no more 'easily cabined' than the idea of Equality." Karst, supra note 72, at 50 (quoting Cox, supra note 158 , at 91). 
true equality would mean. Even more than other areas of constitutional law, equal protection "is as we are; so it is not yet complete."161 What we can reasonably ask of equal protection doctrine, therefore, is not static perfection, but progressive improvement-a "case-by-case, year-by-year resolution of the problem."162 This has been the hope of equal protection law since its inception; it is why the Fourteenth Amendment, like the Fifth Amendment, was framed deliberately in "language capable of growth."163

Growth, however, is not appreciably fostered by the cardinal virtues of the universalist approach: simplicity and consistency. Indeed, given how far we are from reaching full agreement on the nature of equality, the simplicity and consistency of equal protection rules are not simply insignificant virtues; they are outright vices. They are vices because they block the kind of "experimental," dialectic development that has been the historic strength of the common law ${ }^{164}$-and, for that matter, of much of constitutional law. ${ }^{165}$ As a consequence, instead of the "great logical strength in detail and great overall disorder" characteristically produced by that method, ${ }^{166}$ we now have an equal protection law of great folly in detail, great overall order, and little capacity for growth.

\section{B. Disaggregating Equal Protection}

Suppose we gave up, at least for now, our insistence on a unified doctrine of equal protection. Suppose we agreed to tolerate a degree of disorder in equal

161. Phimlip Bobitt, Construmional Fate 242 (1982) ("It has been our destiny to attempt what no society before ours has attempted, the making of justice through a Constitution. ... I I am prepared to believe it holds within it fates as yet unfolded, toward which we are working.").

162. Karst, supra note 72, at 65; see also Jeremy Bentham, The TheORY of Legislation 120 (C.K. Ogden ed., 1931) ("The establishment of perfect equality is a chimera; all we can do is to diminish inequality.").

163. Alexander M. Bickel, The Original Understanding and the Segregation Decision, 69 HaRv. L. REv. 1, 63 (1955).

164. Benjamin N. Cardozo, The Nature of the Judicial Process 22-23, 179 (1921) (quoting Munroe Smith, Jurisprudence 21 (1909)); see also Oliver Wendell Holmis, JR., The Common LAw 5, 31-33 (Mark DeWolfe Howe ed., 1963) (1881); S.F.C. Milsom, Reason in the Development of the Common Law, 81 Law Q. Rev. 496 (1965).

165. Regarding Fourth Amendment law, for example, see Coolidge v. New Hampshire, 403 U.S. 443,483 (1971) ("The time is long past when men believed that development of the law must always proceed by the smooth incorporation of new situations into a single coherent analytical framework."). The internal disorder of Fourth Amendment law has, of course, attracted its share of academic critics. See, e.g., Akhil Reed Amar, Fourth Amendment First Principles, 107 HaRv. L. REv. 757 (1994). But most practitioners probably share Anthony Amsterdam's conclusion that one of the strengths of the Supreme Court's approach to Fourth Amendment law has been the Court's willingness to forego comprehensive theorizing in favor of pragmatic, piecemeal development. See Anthony G. Amsterdam, Perspectives on the Fourth Amendment, 58 MnN. L. REv. 349, 351-53 (1974).

Similarly, instead of trying to craft a single "Free Speech Clause test," the Court has fashioned "different tests for content-based speech restrictions, for content-neutral speech restrictions, for restrictions imposed by the government acting as employer, for restrictions in nonpublic fora, and so on." Board of Educ. of Kiryas Joel Village Sch. Dist. v. Grumet, 114 S. Ct. 2481, 2499 (1994) (O'Connor, J., concurring). Justice O'Connor argued in Kiryas Joel that "[e]xperience proves that the Establishment Clause, like the Free Speech Clause, cannot easily be reduced to a single test." Id. She suggested that "the case law will better be able to evolve" if freed from the "Lemon test's rigid influence." Id. at 2500 (citing Lemon v. Kurtzman, 403 U.S. 602 (1971)).

166. Milsom, supra note 164 , at 513. 
protection law comparable to that found in free speech law or search-andseizure law. How then would a court assess the constitutionality of the federal crack penalties? It might start by asking whether those penalties differ significantly from the subject matter of earlier equal protection cases rejecting claims based on disproportionate impact. If it concluded that they do, a court freed from the universalist approach might then take a fresh look at how equal protection claims could sensibly be assessed in circumstances like those before it. Its exploration of these two questions might resemble the following.

\section{Why the crack sentences are different.}

The crack sentences are criminal sanctions imposed as part of a comprehensive and systematic sentencing code enacted on.the federal level. This distinguishes them in important ways from the vast run of other laws the Supreme Court has upheld against challenges based on racially disproportionate impact.

It matters, to begin with, that the sanctions are criminal. When a law imposes long periods of incarceration-instead of, say, allocating employment opportunities-inequalities attributable to race are especially intolerable. Locking someone up in cage for a period of years is singularly serious business. The text of the Constitution itself recognizes the heightened stakes; criminal sentencing statutes implicate not just equal protection but also due process and the Eighth Amendment's ban on cruel and unusual punishment. ${ }^{167}$ And the stakes are higher not only for those convicted. As the Supreme Court has recognized in the context of jury selection, apparent inequality within the criminal justice system does more than visit unfairness on the defendant; it also "undermine[s] public confidence in the fairness of our system of justice,"168 and serves as a "stimulant to . . r race prejudice." "169

Not only is inequality in criminal sentencing thus unusually damaging, but the grounds for judicial restraint in addressing sentencing inequality are unusually weak. The Supreme Court has frequently expressed reluctance to insert itself into matters outside its traditional domain, or to second-guess the judgment of elected officials about issues beyond the special competence of the judiciary. But criminal sentencing is well inside that domain and close to the core of that competence; while one can argue that school financing should not be the business of the courts, ${ }^{170}$ it is difficult to make a similar argument about sentencing. For this reason, too, a nonuniveralist court might conclude that allegations of inequality in criminal sanctions call for special attention.

This conclusion was not, of course, the one the Supreme Court reached in McCleskey v. Kemp, ${ }^{171}$ when it upheld Georgia's death penalty system in the

167. Cf. Bearden v. Georgia, 461 U.S. 660,665 (1983) (noting that "[d]ue process and equal protection principles converge" in cases concerning criminal prosecution of indigents).

168. Batson v. Kentucky, 476 U.S. 79, 87 (1986).

169. Id. at 88 (quoting Strauder v. West Virginia, 100 U.S. 303, 308 (1880)); cf. Laurie L. Levenson, The Future of State and Federal Civil Rights Prosecutions: The Lessons of the Rodney King Trial, 41 UCLA L. REv. 509, 511 n.4, 527 (1994) (describing the aftermath of acquittals in the state prosecution of white police officers accused of beating a black motorist).

170. See San Antonio Indep. Sch. Dist. v. Rodriguez, 411 U.S. 1, 40-43 (1973).

171. 481 U.S. 279 (1987). 
face of powerful statistical evidence that the system was slightly biased against black defendants, and overwhelmingly biased against defendants whose victims were white. The Court in McCleskey subjected Georgia's death sentences to the familiar doctrinal tests of "discriminatory purpose" and "rational basis," rejecting out of hand the suggestion that allegations of racial inequality in capital punishment might warrant a different approach. ${ }^{172}$ The McCleskey decision provides, in some respects, an even starker illustration than the crack cases of the appalling blindness of our current approach to equal protection. ${ }^{173}$ Even the death sentence affirmed in $\mathrm{McCleskey,} \mathrm{though,} \mathrm{lacked} \mathrm{two} \mathrm{additional} \mathrm{fea-}$ tures of the federal crack penalties that make race-based disparities there particularly indefensible.

The first is that the crack penalties are part of a sentencing system that has intentionally replaced broadly diffused discretion with a uniform and comprehensive set of rules. Much of what motivated the Court in $M c$ Cleskey was the practical difficulty of rooting out racial motivations in a sentencing system that relied heavily on discretionary decisions made by individual judges, jurors, and prosecutors. ${ }^{174}$ Federal prison sentences are no longer set by such a system, ${ }^{175}$ and one of the consequences is that the practical concerns that so worried the Court in $\mathrm{McCl}$ eskey have virtually disappeared.

Equally absent in the cases challenging the federal crack sentences are the federalism concerns lurking in the background of McCleskey. Those concerns have long shaped equal protection law under the Fourteenth Amendment. ${ }^{176}$ They are wholly inapplicable, however, when the federal judiciary assesses the constitutionality of a federal statute under the Fifth Amendment.

The crack penalties are criminal sanctions set by Congress as part of a new federal regime of sentences largely fixed by statute and regulation. They thus differ in significant ways from utility regulations, welfare eligibility rules, and

172. See id. at 292-99.

173. See Robert D. Goldstein, Blyew: Variations on a Jurisdictional Theme, 41 StaN. L. Rev. 469, 555-63 (1989); Johnson, supra note 120; Kennedy, supra note 71.

174. See McCleskey v. Kemp, 481 U.S. at 297 ("Because discretion is essential to the criminal justice process, we would demand exceptionally clear proof before we would infer that the discretion has been abused.") The Court stressed that public policy considerations both "dictate that jurors "cannot be called ... to testify to the motives and influences that led to their verdict,' [and] suggest the impropriety of our requiring prosecutors to defend their decisions to seek death penalties, 'often years after they were made.' "Id. at 296, quoting Chicago, B. \& Q.R. Co. v. Babcock, 204 U.S. 585, 593 (1907), and Imbler v. Pachtman, 424 U.S. 409, 425-26 (1976); cf. Robert A. Burt, Disorder in the Court: The Death Penalty and the Constitution, 85 MrCr. L. Rev. 1741, 1797-98 (1987) (noting that elimination of the racism alleged in $\mathrm{McCleskey}$ would have required the Court "to launch a wholesale restructuring of the system," and that "[t]he current Court has shown little inclination for an unsettling enterprise of this magnitude").

175. Capital sentencing at the federal level remains discretionary. See Federal Death Penalty Act of 1994, Pub. L. No. 103-322, ch. 228, tit. VI, $\S 60002,108$ Stat. 1786 (to be codified at 18 U.S.C. $\S \S 3591-98$ ); GUIDELINES MANUAI, supra note 8, § 2AI.1, application note 2 (sentencing guideline for first-degree murder applies only "when a sentence of death is not imposed").

176. See, e.g., San Antonio Indep. Sch. Dist. v. Rodriguez, 411 U.S. 1, 44 (1972) ("It must be remembered ... that every claim arising under the Equal Protection Clause has implications for the relationship between national and state power under our federal system.'); $c f$. Jonathan D. Varat, State "Citizenship" and Interstate Equality, 48 U. Crr. L. Rev. 487, 571 (1981) (noting in a different context that "[i]ssues of discrimination and issues of federalism are frequently linked in constitutional discourse"). 
even state capital sentencing decisions. Freed from the universalist approach to equal protection, a court might reasonably conclude that the constitutional tests applied in past cases should not automatically be applied to the crack sentences. And instead of attempting to remake all of equal protection doctrine in order to address the concerns raised by the crack sentences, a nonuniversalist court might simply ask how constitutional claims could sensibly be assessed in cases sharing the important characteristics of this one-cases, that is, involving federal sentencing laws with racially disproportionate impacts.

\section{An equal protection test for federal sentencing laws with racially disproportionate impacts.}

Once the questions of racial fairness raised by the federal crack penalties are disaggregated from the broader problem of equal protection in the abstract, they begin to look less formidable. While the dramatically disproportionate impact of the crack penalties on black defendants suggests that conscious or unconscious racism may be at work, it does not prove it. This is a familiar problem in equal protection jurisprudence. But racial discrimination in criminal sentencing is particularly intolerable, and judges are particularly well-suited to scrutinize federal sentencing laws. How could a court sensibly test for racism in this context? One thing it could do is borrow a relatively simple tool developed in other contexts: burden-shifting.

In a range of specialized areas, the Supreme Court has required the government to provide a nondiscriminatory explanation for actions that disproportionately burden a disempowered minority. Burden-shifting based on a showing of disproportionate impact is well established, for example, in cases involving statutory claims of discrimination, ${ }^{177}$ constitutional challenges to jury selection, ${ }^{178}$ and remedial challenges to school segregation. ${ }^{179}$ In each of these contexts, burden-shifting has provided a pragmatic, relatively simple way of resolving particular claims of unfairness, without requiring general agreement on what would constitute perfect fairness. Indeed, one of the great virtues of the burden-shifting approach is that it can appeal both to those who share the dominant process-oriented view of equal protection and to those who believe the goals of equal protection should be substantive. The former can view burden-shifting as a means to test for legitimate motive, while the latter can view it as a way of requiring special justification for permitting disproportionate impact. ${ }^{180}$

177. See Griggs v. Duke Power Co., 401 U.S. 424 (1971).

178. See Batson v. Kentucky, 476 U.S. 79 (1986); Castaneda v. Partida, 430 U.S. 482 (1977).

179. See Swann v. Charlotte-Mecklenberg Bd. of Educ., 402 U.S. 1 (1971).

Similar rules have also been applied under the Commerce Clause to certain state statutes that disproportionately burden out-of-state interests, even "incidental[ly.]" Pike v. Bruce Church, Inc., 397 U.S. 137, 142 (1970); see also Hunt v. Washington State Apple Advertising Comm'n, 432 U.S. 333, 350-53 (1977); cf. Julian N. Eule, Laying the Dormant Commerce Clause to Rest, 91 Y ALE L.J. 425, 446-74 (1982) (proposing heightened judicial attention, under the Privileges and Immunities Clause of Article IV, to state laws imposing disproportionate burdens on unrepresented outsiders).

180. See, e.g., George Rutherglen, Disparate Impact Under Title VII: An Objective Theory of Discrimination, 73 VA. L. REv. 1297, 1313-14 (1987). 
Freed from the universalist approach to equal protection, a court might well find that the Supreme Court's burden-shifting cases offered more helpful guidance than Washington v. Davis and McCleskey v. Kemp for assessing the constitutionality of the federal crack penalties. It might therefore conclude that when a federal sentencing rule is shown to have a seriously disproportionate impact on black defendants-and certainly when it is shown to impose burdens almost exclusively on black defendants - the government should be required to rebut the inference of conscious or unconscious racism by providing an alternative explanation for the rule. And in order to protect against unconscious racism in the extent of differential treatment, it might reasonably ask the government to provide a neutral explanation not just for the distinction Congress drew, but also for what it did with that distinction-a neutral explanation, for example, not just for setting separate quantity thresholds for crack, but also for setting them at one percent of the thresholds for its precursor, powder cocaine.

It is easy to exaggerate the difficulty of satisfying this requirement. How, one might ask, could the government possibly justify any particular sentencing ratio? Aren't all numbers ultimately arbitrary? Yes and no. There certainly are no unique, objectively correct levels at which to set the narcotic quantity thresholds for mandatory minimum sentences. But that hardly means the government can never explain the particular thresholds it has selected. In many cases it can. The quantity thresholds for marijuana, for example, are 1000 times higher than those for heroin. ${ }^{181}$ This differential treatment, like the differential treatment of crack and powder cocaine, has a racially disproportionate impact, because blacks comprise a significantly greater share of heroin defendants than of marijuana defendants. ${ }^{182}$ But there is a racially neutral explanation for the 1000:1 ratio between quantity thresholds for marijuana and heroin: Congress believed that a defendant needs roughly 1000 times more marijuana than heroin to qualify as a major or middle-level trafficker. ${ }^{183}$

The crack penalties are different. They would fail the test. It does not appear the government could provide a racially neutral explanation for treating fifty grams of crack the same as five kilograms of cocaine. The 100:1 ratio was selected too capriciously. As a result, there is no basis for disregarding the risk identified by process theory-the risk that the crack penalties are so severe at least in part because they fall almost entirely on blacks. A nonuniversalist court that took that risk seriously might well insist on a racially neutral explanation for the severity of the crack sentences. And a court that imposed such a requirement would find the sentences unconstitutional.

181. See 21 U.S.C. $\$ 841$ (b)(1)(A)(i), (vii) (1988 \& Supp. V 1993) (imposing a 10-year mandatory minimum sentence for trafficking in one kilogram of a mixture or substance containing a detectable amount of heroin or 1000 kilograms of a mixture or substance containing a detectable amount of marijuana).

182. See 1993 Annual Report, supra note 5, at 152 (indicating that $36.8 \%$ of heroin defendants and $4.2 \%$ of marijuana defendants are black; $13.1 \%$ of heroin defendants and $46.9 \%$ of marijuana defendants are white).

183. See notes 15-17 supra and accompanying text. 


\section{Unanswered Questions and the Development of the Law}

I have suggested one way in which a court freed from the universalist approach to equal protection might assess the constitutionality of the federal crack sentences. The course I have suggested purposely leaves much unanswered about how later cases would be resolved. For example, once the burden has shifted to the government to provide a racially neutral explanation for a sentencing statute with a disproportionate impact, what kinds of explanations should the government be permitted to offer? Must the explanation be one provided by Congress or the Sentencing Commission itself? What if the explanation appears wholly pretextual?

And what kinds of explanations, even if fully credited, should count as racially neutral? How, for example, should courts handle racially disproportionate sentencing differentials based on historical sentencing practices? The Sentencing Guidelines, for example, escalate a defendant's sentencing range by fixed increments based on the defendant's prior criminal record. ${ }^{184}$ The Sentencing Commission determined the size of the increments largely through an empirical analysis of sentences imposed before promulgation of the guidelines. ${ }^{185}$ Black defendants on average have significantly worse criminal records than white defendants. ${ }^{186}$ Should courts accept reliance on past sentencing practices as a racially neutral explanation for sentencing provisions with disproportionate impacts? Or does reliance on past practices simply perpetuate past racism, conscious or unconscious? And does the willingness of the Sentencing Commission to tolerate this effect itself reflect unconscious racism? ${ }^{187}$

None of these questions are presented by the crack sentences, but they are bound to arise in later cases. If I were forced to answer them today, I would say, contrary to current law, ${ }^{188}$ that a racially neutral explanation for a federal sentencing rule should count for equal protection purposes only if it appears factually plausible, because an explanation that Congress or the Sentencing Commission plainly did not consider can provide little assurance that the severity of the rule is unrelated to its racial impact. And I would say that an explanation accepted as factually plausible should count as racially neutral as long as it is neutral on its face, because such a rationale, even if it has the effect of perpetuating past racism, at least answers the most pressing concern of process theory: the concern that a particular burden is so severe simply because the majority cares so little about those upon whom the burden is imposed.

184. See GuIdelines Manuat, supra note 8 , ch. 4 , $\S 5$ H1.8 to 1.9 .

185. See id. ch. 1, pt. A(3).

186. See Joan Petersilia \& Susan Turner, Gundelme-Based Justice: The Implications for RActal Minorities 14-19 (1985).

187. Cf. Lawrence, supra note 120 , at 342 (arguing that unconscious racism can take the form of a "failure to see the implicit racism in a racially neutral line of reasoning"); Charles J. Ogletree, Jr., The Death of Discretion? Reflections on the Federal Sentencing Guidelines, 101 HaRv. L. REv. 1938, 1958 \& n.119 (1988) (suggesting that if "racial disparities persist under the guidelines . . . the [Sentencing] Commission should ... consider more direct means of addressing the problem[,]" such as eliminating sentence enhancements for prior criminal history).

188. See note 100 supra and accompanying text. 
But I do not think courts should try to answer these questions today. Nor should they attempt to catalog in advance all the settings, beyond federal criminal sentencing laws with racially disproportionate impacts, that might benefit from the burden-shifting test I have described. The point of disaggregating equal protection is to foster gradual, experimental growth of the law. For that growth to begin, courts must be free to devise workable responses to particular, distinctive problems of equal protection, such as the racial fairness of the federal crack penalties, without determining in advance the implications of their reasoning for all other contexts.

To some, judicial freedom of this kind will look like something of a copout. As Herbert Wechsler asked, isn't "the very essence of judicial method" a commitment to deciding cases "on grounds of adequate neutrality and generality, tested not only by the instant application but by others that the principles imply?"189 Shouldn't we want judges to strive, in Ronald Dworkin's words, for "articulated consistency, decisions in accordance with a program that can be made public and followed until changed"?190 Even if the law is not a "seamless web," aren't parties entitled to ask judges "to treat it as if it were"?191

In theory, maybe. Were it possible, it might well be preferable for courts to work out rules of equal protection in the manner suggested by Wechsler and Dworkin. The rub is that, in practice, it does not seem to have worked. Dworkin illustrated his ideal model of adjudication through the use of an imaginary jurist named Hercules, ${ }^{192}$ and the mythological reference is fitting. In the real world, for real judges, equality has simply proven too tough a problem for the universalist approach. Wechsler's test has screened out all but the feeblest rules of equal protection. Worse, it has blocked consideration of claims we should want our law to take seriously, and it has prevented, for the most part, what we should want most from equal protection law: a process for developing and refining, case by case, our collective understanding of the meaning of equality.

I say "for the most part" because equal protection law has contributed to such a process in some areas-precisely those areas, though, where the Supreme Court has strayed from the universalist approach. For example, the relative success of equal protection law over the past several decades in making elections fairer and juries more representative may not be unrelated to the Supreme Court's willingness to develop specialized sets of rules for evaluating equal protection challenges in these settings.

Nor is it accidental, perhaps, that the proudest achievement of equal protection law, Brown v. Board of Education, ${ }^{193}$ represented an almost complete abandonment of the universalist approach. There was nothing about tiers of scrutiny in Brown, nothing about any overarching rules of decision. Instead, (1959).

189. Herbert Wechsler, Toward Neutral Principles of Constitutional Law, 73 HARv. L. REv. 1, 15

190. DwORKIN, supra note 72 , at 162.

191. Id. at 116.

192. See id. at 105-30.

193. 347 U.S. 483 (1954). 
the Court focused on one specific part of the meaning of equality: "[I]n the field of public education the doctrine of 'separate but equal' has no place."194 No one could doubt that Brown would have implications outside the schoolhouse, but the Court left those implications to be worked out later, case by case.

Precisely for this reason, Wechsler found the Brown opinion unsatisfactory and the decision itself problematic; he confessed himself unable to discern "a basis in neutral principles" for the Court's holding. ${ }^{195}$ Thirty-five years later, finding "neutral" justifications for Brown seems less difficult, in large measure because many of the implications of Brown, worked out in scores of later cases, seem less foreboding now than they did in 1959. It no longer seems so odd, for example, for constitutional litigation to "involve an inquiry into the motives of the legislature."196 Nor do the hypothetical cases Wechsler posed in 1959 seem very troubling today, now that they have actually been confronted: "Does enforced separation of the sexes discriminate against females merely because it may be the females who resent it and it is imposed by judgments predominantly male? Is a prohibition of miscegenation a discrimination against the colored member of the couple who would like to marry?"197

Parades of horribles often look less horrible up close. In retrospect, Wechsler's difficulty justifying Brown under "neutral principles" seems less a sign that the decision may have been wrong than that the universalist approach, even in the hands of someone as imaginative as Wechsler, is a poor way to develop a meaningful law of equal protection.

The crack cases, I have tried to show, teach much the same lesson. They suggest that our current approach to equal protection, an approach by and large faithful to Weschler's dictates, has wound up rendering far too much of what matters in the world legally invisible. By demanding too much doctrinal order, we have produced a doctrine that demands too little justice.

194. Id. at 495 .

195. Wechsler, supra note 189 , at 34.

196. Id. at 33.

197. Id. at 33-34. 